\title{
Zasady merytokratyczne w polityce państwa - wzloty i upadki
}

\begin{abstract}
Streszczenie
Autor analizuje czynniki, które osłabiają oddziaływanie zasad merytokracji na instytucje i politykę państwa. Wskazuje, że merytokratyczne podejście do rządzenia, w tym programowania działań publicznych, jedynie w ograniczonym zakresie stało się zasobem służącym do uzyskiwania prawomocności władzy w Polsce. Atuty merytokracji (jak „wydajność” i „sprawiedliwość”) nie zostały w tym celu uruchomione w znaczącej skali. W konsekwencji doszło do znaczącego delegitymizowania prawomocności ustroju demokratycznego, a także osłabienia identyfikacji społeczeństwa z państwem. Miarą tego zjawiska jest m.in. niski prestiż polityków i duża absencja wyborcza. Autor zwraca uwagę na to, że mechanizmy zarządzania merytokratycznego w instytucjach publicznych w Polsce są znacząco zredukowane z uwagi na oddziaływanie wielu czynników - zawłaszczanie państwa przez partie polityczne, instytucjonalny nomadyzm elit, reguły kapitalizmu politycznego, miękkie państwo i instytucjonalizację nieodpowiedzialności lub działań rozmaitych grup interesu i zakulisowych podmiotów polityki.
\end{abstract}

Słowa kluczowe: socjologia, polityka publiczna, merytokratyzm, legitymizacja, państwo

UPS and Downs of Maritocratic Principles of Public Policy

\begin{abstract}
The author analyses the factors that weaken the influence of the principles of meritocracy on the institutions and public policy. He indicates that a meritocratic approach to governance in the programming of public actions has become a resource for obtaining legitimacy of power in Poland to a limited extent. The advantages of meritocracy (the "efficiency" and "justice") have not been exploited on a significant scale. As a result, there is a significant illegitimacy of the democratic system, as well as the weakening of the society identification with the state. This phenomenon is characterized by low prestige of politicians and a poor voter turnout. The author draws attention to the fact that meritocratic management mechanisms of public institutions in Poland are significantly
\end{abstract}


reduced due to numerous factors - the appropriation of the state by political parties, institutional nomadism of the elite, the rules of political capitalism, a soft state and the institutionalization of non-responsibility or activities of various interest groups and backstage actors of politics.

Keywords: sociology, public policy, meritocratism, legitimacy, state

Merytokracja jest uznawana za jedno ze źródeł legitymizacji współczesnego systemu sprawowania władzy i rządzenia. Innymi słowy, stała się ważnym źródłem prawomocności władzy, jej akceptacji i uzasadnienia funkcji, którą pełni ona w społeczeństwie. Oddziaływanie idei merytokratycznych dotyczy również państw odbiegających od reguł zachodniej demokracji, czego przykładem jest spektakularny rozwój gospodarczy Azji Wschodniej zapoczątkowany w latach 60. XX w., którego ważną determinantą było m.in. stworzenie w państwach autorytarnych kompetentnej administracji publicznej, umiejętnie łączącej długookresowe strategie zmian ekonomicznych ze społeczną legitymizacją ich kierunku'.

Merytokracja stała się synonimem ustroju państwowego, w którym rządy sprawują (lub powinni sprawować) ludzie najlepiej do tego przygotowani - kompetentni i profesjonalni. To koncepcja sposobu funkcjonowania państwa, która dobrze koresponduje z ideologiczną racjonalnością „dojrzałego” kapitalizmu ukształtowanego na Zachodzie po II wojnie światowej. Stanowi odpowiedź na potrzebę wprowadzenia nowych form działania państwa, w którym istnieją realne mechanizmy zapewniające mobilność społeczną, nowe źródła kształtowania hierarchii władzy, własności i prestiżu.

Zdaniem G. Marshalla i A. Swifta ${ }^{2}$, zasady merytokratyzmu znalazły we współczesnych społeczeństwach pozytywny odbiór jako wydajne i sprawiedliwe. Zgodnie z nimi wysoką wydajność mogą bowiem osiągać przede wszystkim „najlepiej przygotowani”, których odsuwanie od zadań i wysokich pozycji byłoby marnotrawstwem kapitału ludzkiego sprzecznym z interesami społeczeństwa. Orientacja merytokratyczna jest uważana za sprawiedliwą, ponieważ powszechnie akceptuje się pogląd, że dobrze wykwalifikowane jednostki (wyróżniające się cechami najlepiej pasującymi do wykonywania danej pracy), zasługują również na wysokie wynagrodzenia ${ }^{3}$. „Nagra-

1 The World Bank, The East Asian Miracle, Oxford University Press, Oxford 1993.

2 G. Marshall, A. Swift, Meritocratic Equality of Opportunity: Economic Efficiency, Social Justice, or Both?, "Policy Studies" 1997, No. 18, s. 35-48.

3 K.M. Słomczyński (1998) rozróżnił dwa rodzaje merytokratyzmu: alokacyjny i dystrybucyjny. Pierwszy rozpatruje dopasowanie wykształcenia do wymogów kwalifikacyjnych pozycji zawodowych. Natomiast drugi skupia się na korelacji zarobków z poziomem kwalifikacji mierzonych poziomem wykształcenia. 
dzanie według zasług" często jest również kojarzone z zasadą równych możliwości, która motywuje i gratyfikuje szczególny wkład niektórych jednostek, niezbędny dla rozwoju społeczeństwa ${ }^{4}$. W ten sposób „wiara w legalność”, zdaniem Webera będąca „najpowszechniejszą formą uprawomocnienia”, została trwale spleciona z ideologiczną orientacją merytokratyczną i efektywnościową. Została także mocno powiązana z deklaracjami równych możliwości wejścia do warstwy „najlepiej wykwalifikowanych”, uznawanych za główną siłę sprawczą nowoczesności.

Merytokrację można uznać za pewne uzupełnienie Weberowskiej koncepcji panowania racjonalno-legalnego. Utrwaliła ona dominację orientacji prawniczej i instytucjonalnej w państwie. Wskazuje na kluczową rolę procedur formalnych, najsprawniej wytwarzanych i wdrażanych przez biurokrację rozumianą jako profesjonalna grupa zawodowa, której wyróżnikami są m.in. wiedza oraz personalne kwalifikacje potwierdzane egzaminem czy dyplomem ${ }^{5}$.

Wraz z upadkiem komunizmu w Polsce i innych państwach Europy Środkowej i Wschodniej orientację merytokratyczną rozpatrywano przede wszystkim jako składnik nowoczesnych rozwiązań instytucjonalnych. Takie podejście jest dobrze ugruntowane w teoriach modernizacji i konwergencji, które akcentują kluczową rolę profesjonalnych elit w inicjowaniu oraz przeprowadzaniu zmian społecznych ${ }^{6}$. Jest też ono silnie akcentowane w dyskusjach wokół funkcjonalnej teorii stratyfikacji społeczeństwa. Skupia ona uwagę na determinantach, które powodują rozwarstwianie się nowoczesnego społeczeństwa ${ }^{7}$. Przedstawiciele tej orientacji rozpatrują indywidualne osiągnięcia jednostek jako jeden $z$ uniwersalnych czynników kształtujących strukturę społeczną. Zakładają, że jednostka osiąga określoną pozycję w strukturze społecznej dzięki osobistym zasługom (wysiłkom, zdolnościom, kompetencjom).

Krytycy takiego podejścia akcentują jednak, że baza rekrutacyjna merytokracji jest zawężona przede wszystkim do uprzywilejowanych warstw społecznych, które wyróżniają się ponadprzeciętnym majątkiem i kapitałem kulturowym. Merytokrację przedstawia się zwykle jako pojęcie egalitarne, gdyż formalnie tworzy ona system otwarty dla każdego, kto wykaże się odpowiednimi zasługami. Jednak pochodzenie społeczne i status materialny są jednymi z najczęściej wskazywanych strukturalnych czynników ograniczających zakres merytokratyzmu w społeczeństwie, co sprawia,

4 S. White, Równość, Sic!, Warszawa 2008.

5 M. Weber, Gospodarka i społeczeństwo, Wydawnictwo Naukowe PWN, Warszawa 2002.

6 N. Gilman, Mandarins of the Future. Modernization Theory in Cold War America, The Johns Hopkins University Press, Baltimore-London 2007.

7 Zob. W. Wesołowski, Merytokracja, w: Encyklopedia Socjologii, t. 2, Oficyna Naukowa, Warszawa 1999; K.M. Słomczyński, „Merytokratyzm” a efektywność alokacyjna i dystrybucyjna w Polsce w latach 1965-1995, w: Do i od socjalizmu, red. A. Siciński, Wydawnictwo IFiS PAN, Warszawa 1998. 
że bez mechanizmów wyrównujących szanse niższych warstw społecznych staje się on ideologią korzystną dla uprzywilejowanych ${ }^{8}$.

\section{Merytokracja w Europie Środkowo-Wschodniej}

Względnie łatwo uzasadnić tezę, że przebieg przemian ustrojowych w Polsce (jak w innych państwach Europy Środkowej i Wschodniej) jedynie częściowo oraz wybiórczo sprzyjał wprowadzaniu zasad merytokracji. Warto jednak przypomnieć, że postulat merytokratyzmu ma swoją szczególną historię w regionie. Po II wojnie światowej był traktowany jako instrument krytyki socjalizmu państwowego. Krytycy tego ustroju postulowali bowiem „odpartyjnienie” zarządzania i zwiększanie zastosowania zasad merytokratycznych na wzór społeczeństw zachodnich. Opowiadali się za reformami zmierzającymi do wdrożenia bardziej technokratycznych reguł. Ich zdaniem, jednym $z$ argumentów delegitymizujących poprzedni ustrój był słaby związek zarobków z wykształceniem, sprzeczny z postulatem merytokracji dystrybucyjnej przypisywanej rozwiniętym państwom kapitalistycznym.

Nie ulega wątpliwości, że zmiana ustrojowa nadała orientacji merytokratycznej większe znaczenie (chociaż ustalenie, $w$ jakiej mierze jest ona faktycznie akceptowana wśród rządzących, jak i rządzonych, podobnie jak określenie sfer, w których ona przeważa, wymagają pogłębionych badań). Reformy rynkowe spowodowały, że mechanizmy zróżnicowań dochodów stały się bardziej merytokratyczne, chociaż znaczne kontrowersje budzą zakres i następstwa występowania tej tendencji, m.in. ze względu na odmienności źródeł danych, metod pomiaru i interpretacji ${ }^{9}$.

Od początku przemian ustrojowych w Polsce nasila się tendencja do postrzegania wykształcenia i kwalifikacji jako warunków koniecznych w rozwoju kariery zawodowej, co świadczy o nobilitacji merytokracji, osobistych zasług, inicjatywy i przedsiębiorczości. Równocześnie jednak występuje odmienny pogląd, że niezbędnym warunkiem powodzenia jest zamożność rodziców oraz rozpowszechnione jest przeświadczenie (zwłaszcza wśród osób o niższych dochodach i gorzej wykształconych), iż szanse na sukces materialny zwiększa wykorzystanie luk prawnych bądź omijanie prawa ${ }^{10}$.

8 Zob. klasyczne analizy zróżnicowań szans szkolnych w zależności od pochodzenia społecznego (P. Bourdieu, J.C. Passeron, Reprodukcja, Wydawnictwo Naukowe PWN, Warszawa 1990), a także uwagi na temat nowego podziału takich szans w okresie globalizacji (U. Beck, Społeczeństwo ryzyka, Wydawnictwo Naukowe Scholar, Warszawa 2002).

9 K.M. Słomczyński, K. Janicka, Pęknięta struktura społeczeństwa polskiego, w: Polska. Ale jaka?, red. M. Jarosz, Instytut Studiów Politycznych PAN, Warszawa 2005; H. Domański, Struktura społeczna, Wydawnictwo Naukowe Scholar, Warszawa 2004, s. 231-236.

${ }_{10}$ B. Badora, W. Derczyński, M. Falkowska, Nierówności społeczne, w: Polska Europa Świat. Opinia publiczna w okresie integracji, red. K. Zagórski, M. Strzeszewski, Wydawnictwo Naukowe Scholar, Warszawa 
W świadomości społecznej zakres merytokracji jest zatem ograniczany przez pochodzenie i status majątkowy. Merytokrację można też „zastąpić” korupcją i „elastycznym” traktowaniem prawa, co częściej mogą praktykować przedstawiciele elit społecznych dysponujący większymi zasobami i instrumentami działania niż inne środowiska społeczne. Przejawem takich zjawisk w sektorze publicznym są dokonywane przez kolejne rządy zmiany w ustawie o służbie cywilnej oraz praktyki obsady kierowniczych stanowisk w administracji państwowej i samorządowej, a także w spółkach skarbu państwa, skorelowane z tzw. cyklem wyborczym.

W efekcie główna teza tego opracowania przyjmuje, że merytokratyzm jedynie w ograniczonym zakresie stał się zasobem uprawomocnienia władzy w Polsce. Można stwierdzić - nawiązując do uwag S.M. Lipseta na temat czynników ustanawiających legitymizację - że atuty merytokracji (jak „wydajność” i „sprawiedliwość”) nie zostały w tym celu uruchomione w znaczącej skali.

W Polsce widoczna jest powszechna krytyka sposobu działania instytucji publicznych. Rządzący nie są postrzegani w kategoriach warstwy „najlepiej przygotowanej”, co znajduje odzwierciedlenie w krytycznych ocenach efektów ich działania w świadomości społecznej.

Merytokratyzm w Polsce jest traktowany raczej jako postulat normatywny bądź pewna ideologia użyteczna dla uzasadniania przywilejów części nowych elit niż praktyka tworzenia mechanizmów promujących ludzi kompetentnych, osiągających wysoką pozycję społeczną dzięki swoim osobistym walorom i zasługom. W artykule charakteryzuję wybrane czynniki, które przyczyniają się do osłabienia zasad merytokracji w Polsce. Ich występowanie znacząco osłabia prawomocność nowego ustroju, a także pomniejsza identyfikację z nim znacznej części społeczeństwa, czego miarą jest m.in. niski prestiż polityków i duża absencja wyborcza. Stawiam także tezę, że jedną z zasadniczych przyczyn słabości merytokratyzmu w Polsce jest dominacja w polityce państwa jego „słabej” interpretacji, która w niewielkim zakresie działa na rzecz równych możliwości.

Bezpośrednim impulsem dla sformułowania powyższych tez są wyniki międzynarodowych badań dotyczących zdolności zarządzania instytucjami państwowymi. Bank Światowy i Unia Europejska od lat zwracają bowiem uwagę, że Polska pomimo pewnej poprawy zajmuje dalekie miejsca w międzynarodowych rankingach efektywności rządzenia - Worldwide Governance Indicators ${ }^{11}$ i Regional Governance

2005, s. 202-203; M. Goszczyńska, Percepcja nierówności, statusu materialnego i tolerancja wobec bogatych $w$ polskim społeczeństwie, w: Społeczeństwo w czasach zmiany, red. P. Radkiewicz, R. Siemieńska, Wydawnictwo Naukowe Scholar, Warszawa 2009, s. 54.

11 Obecnie Polska zajmuje 54. miejsce w tym rankingu wśród 209 badanych państw. Analizowane są wskaźniki w sferze wolności słowa i odpowiedzialności, stabilności politycznej i braku przemocy, efektywności rządzenia, jakości regulacji, rządów prawa oraz kontroli korupcji. 
Matters ${ }^{12}$. Porównanie ich wyników w różnych wymiarach pokazuje, że Polska znajduje się wśród słabo zarządzanych państw w UE - zwłaszcza pod względem jakości usług publicznych, jakości służby cywilnej czy stopnia jej niezależności od nacisków politycznych, a także jakości formułowania i wdrażania polityki oraz wiarygodności $\mathrm{rządu}^{13}$. W ostatnich latach poprawiał się nieco wizerunek Polski w tym zakresie. Jest jednak dyskusyjne, na ile ta zmiana świadczy o podniesieniu wskaźników efektywności rządzenia w sektorze publicznym w Polsce (np. gdy uwzględni się sytuację w różnych obszarach usług tego sektora), a w jakiej mierze odzwierciedla ona zmiany tła porównawczego, zwłaszcza w wyniku kryzysu gospodarczego w wielu krajach $\mathrm{UE}^{14}$.

Zinnych źródeł wiadomo bowiem, że niski poziom efektywności rządzenia, będącej jednym z przejawów merytokratyczności systemu władzy, przekłada się na niską legitymizację III RP, mierzoną wskaźnikami poparcia obywateli dla polityków i oceny działalności instytucji publicznych. Wyniki badań realizowanych w międzynarodowym projekcie European Social Survey (ESS) przeprowadzonym w 21 krajach na reprezentacyjnych próbach dowodzą, że najniższa legitymizacja systemu w tej grupie państw występuje w Polsce. Najsilniejsza legitymizacja - definiowana na potrzeby ESS jako pewna postawa wyrażająca określony stopień poparcia dla polityki ekonomicznej, rządu i demokracji - występuje w społeczeństwach skandynawskich, w Luksemburgu i Szwajcarii, tj. stosunkowo małych i ustabilizowanych demokracjach zachodnich, reprezentujących typ welfare state.

Wśród wyjaśnień takiej sytuacji w Polsce wskazywano słabość elit, w tym ich brak kompetencji i profesjonalizmu, karierowiczostwo, przedkładanie interesów partyjnych nad rację stanu, tworzenie chaosu regulacyjnego i prawnego, a także korupcję ${ }^{15}$. Badania opinii publicznej od wielu lat wskazują na słabą identyfikację znaczącej części społeczeństwa $\mathrm{z}$ istniejącym systemem politycznym, $w$ tym $\mathrm{z}$ jego instytucjami. O ile np. w 2008 r. ok. 40 proc. Polaków źle oceniało pracę Sejmu, to w 2015 i 2016 r. - 60 proc. rodaków formułowało taką ocenę ${ }^{16}$. Taki stan rzeczy sprzyja pytaniom

12 Ranking jakości zarządzania państw UE, w którym Polska wyprzedza jedynie Rumunię i Bułgarię, charakteryzuję szerzej w: K. Jasiecki, Kapitalizm po polsku. Między modernizacją a peryferiami Unii Europejskiej, Wydawnictwo IFiS PAN, Warszawa 2013, s. 220-221.

13 Pewnym wyjątkiem jest raport Doing Business, który pokazuje, że Polska systematycznie poprawia swoje regulacje gospodarcze i zajmuje obecnie 25. miejsce wśród 189 państw. Najnowsza edycja Doing Business 2016: Measuring Regulatory Quality and Efficiency zawiera dane porównawcze dotyczące 189 krajów. Agreguje je w 10 obszarach kluczowych dla prowadzenia działalności gospodarczej, jak rozpoczynanie biznesu, efektywność kontraktów, płacenie podatków czy rejestracja własności.

${ }^{14}$ Możliwe jest łączne występowanie tych dwóch przyczyn, jak w zakresie zbliżania się polskiego PKB do średniej unijnej w okresie kryzysu lub niewielkiego wzrostu gospodarczego większości państw członkowskich.

${ }^{15}$ H. Domański, Legitymizacja systemu politycznego w dwudziestu jeden krajach, „Studia Socjologiczne” 2005, nr 2, s. 5-39.

${ }^{16}$ Oceny instytucji publicznych, CBOS, Warszawa, maj 2016. 
o czynniki ograniczające zastosowanie zasad merytokratyzmu, a także ich wpływ na legitymizację nowego ustroju. Nawet pobieżny przegląd informacji z mediów, badań opinii lub publikacji naukowych sugeruje, że działalność instytucji ustrojowych w Polsce w ograniczonym zakresie nadaje się do oceny w kategoriach merytokracji. Nie brakuje także sygnałów, że aktywność profesjonalistów w instytucjach publicznych natrafia na bariery i ograniczenia, które negatywnie modyfikują efekty ich działań.

\section{Teoria i praktyka merytokratyzmu}

Zagadnienie merytokratyzmu było przedmiotem dyskusji teoretycznych po upadku komunizmu, jakkolwiek w latach 90 . nie było wiodącym przedmiotem zainteresowania socjologów i politologów. Później również nie doszło w tym zakresie do jakiejś widocznej zmiany. Dawało się zauważyć założenie, że zasadniczy kierunek reform systemowych relatywnie szybko wzmocni poziom merytokracji w Europie Wschodniej na wzór zachodni. Wpływowym przykładem takiego podejścia stały się badania w ramach „paradygmatu elitystycznego”, który skupiał się na analizach zachowań „starych” $i$ „nowych” elit ${ }^{17}$.

Kwestię merytokratyczną zwykle rozpatrywano jako część procesów modernizacji uruchamiających zmiany strukturalne związane z regułami rynku i kapitalizmu, ekspansją klas średnich oraz typowymi dla nich standardami działania. Ich dopełnieniem (a także ważnym katalizatorem), miała być reorientacja na Zachód, w tym wejście w proces integracji europejskiej. Miała temu służyć również aktywność inwestorów zagranicznych promujących nowe wzorce aktywności ekonomicznej i społecznej, a także transfer instytucji politycznych i gospodarczych z Unii Europejskiej do Polski (przyjęcie acqui communitaire, niezależność Banku Centralnego, pozycja ustrojowa Trybunału Konstytucyjnego itd.).

Wkrótce pojawiły się jednak prace, które zwracały uwagę na to, że rzeczywistość rozmija się z założeniami przyjmowanymi w normatywnych analizach zmian ustrojowych i społecznych. Wielu uczonych zwracało uwagę na uwarunkowania i strategie działań kluczowych podmiotów transformacji, które radykalnie odbiegały od zachodnich postulatów merytokratyzmu alokacyjnego lub dystrybucyjnego. Można w tym zakresie przywołać m.in. prace dotyczące „spółek nomenklaturowych”

${ }^{17}$ J. Higley, J. Pakulski, Elite Theory and Research in Postcommunist Societies, w: The Second Generation of Democratic Elites in Central and Eastern Europe, red. J. Frentzel-Zagórska, J. Wasilewski, Wydawnictwo ISP PAN, Warszawa 2000; Poczatki parlamentarnej elity, red. J. Wasilewski, W. Wesołowski, Wydawnictwo IFiS PAN, Warszawa 1992. 
i klientelizmu ${ }^{18}$, konwersji kapitału politycznego w kapitał ekonomiczny ${ }^{19}$, „instytucjonalnego nomadyzmu” elit realizujących własne interesy ${ }^{20}$, reguł „kapitalizmu politycznego" $i$ „,kapitalizmu sektora publicznego" ${ }^{21}$ bądź ,instytucjonalizacji nieodpowiedzialności” w strukturach „miękkiego" państwa ${ }^{22}$.

Podobne zjawiska zaczęto dostrzegać także w skali całego regionu (transition countries), głównie rolę nieformalnych reguł opartych często na sieciach dyskrecjonalnych powiązań personalnych i instytucjonalnych. Badacze przekształceń własnościowych na Węgrzech rozwinęli analizę restrukturyzacyjnych sieci powiązań między podmiotami politycznymi i gospodarczymi, które ich zdaniem kształtowały nowe wzory własności przetasowanej (recombinant property), będącej podstawą postkomunistycznych stosunków własnościowych i gospodarczych ${ }^{23}$. Owe nowe wzory sieci powiązań i własności (pomiędzy sektorem publicznym i sektorem prywatnym, inwestorami zagranicznymi i kapitałem krajowym itd.), bywają uznawane za jeden z wyróżników regionalnej odmiany gospodarki rynkowej i demokracji - „kapitalizmu wschodnioeuropejskiego"24.

W opinii J.R. Wedel ${ }^{25}$, „nieformalne grupy i sieci kształtowały - i nadal kształtują - wiele kluczowych aspektów procesów ekonomicznych, politycznych i społecznych w Europie Środkowo-Wschodniej i dawnym Związku Radzieckim, w tym dystrybucję i zarządzanie zasobami, tworzenie ścieżek prywatyzacji i własności, struktury wpływu i być może realny kształt państwa”. Jakie są konsekwencje obecności tego rodzaju grup i sieci?

Niekiedy uznawane są one za efektywną strategię wykorzystania zasobów „starego systemu" w nowych warunkach zmian ustrojowych ${ }^{26}$. Znacznie częściej rozpatrywane są one jednak jako ambiwalentne bądź leżące u podstaw wielu systemowych

18 J. Tarkowski, Socjologia świata polityki, t.1, Wydawnictwo ISP PAN, Warszawa 1994.

19 J. Wasilewski, E. Wnuk-Lipiński, Polska: kręta droga od elity komunistycznej do postsolidarnościowej, w: Elity w Polsce, Rosji i na Wegrzech, red. I. Szelenyi, D. Treiman, E. Wnuk-Lipiński, Wydawnictwo ISP PAN, Warszawa 1995.

20 A. Kamiński, J. Kurczewska, Institutional Transformations in Poland: The Rise of Nomadic Political Elites, w: The Transformation of Europe, red. M. Alestalo, E. Allard, W. Wesołowski, Wydawnictwo IFiS PAN, Warszawa 1994.

${ }^{21}$ J. Staniszkis, Postkomunizm, Wydawnictwo słowo/obraz/terytoria, Gdańsk 2001.

22 J. Hausner, M. Marody, Jakość rządzenia: Polska bliżej Unii Europejskiej?, Akademia Ekonomiczna - Fundacja im. Friedricha Eberta, Kraków 2000.

23 D. Stark, L. Bruszt, Postsocialist Pathways. Transforming Politics and Property In East Central Europe. Cambridge University Press, Cambridge 1998.

${ }^{24}$ D. Stark, Recombinant Property in East European Capitalism, "American Journal of Sociology" 1996, No. 101.

25 J.R. Wedel, Klany, kliki i zawłaszczone państwo. O przedefiniowaniu „przejścia” w Europie Środkowo-Wschodniej i dawnych republikach Związku Radzieckiego, w: Szara strefa przemocy - szara strefa transformacji? Przestrzenie przymusu, red. R. Sojak, Uniwersytet Mikołaja Kopernika, Toruń 2007, s. 88.

26 D. Stark, L. Bruszt, op.cit. 
dysfunkcji i patologii, w tym znacznej nieprzejrzystości systemowych reguł gry podporządkowującej zasady merytokratyczne innym motywacjom: preferencjom politycznym, interesom grupowym, jednostkowym korzyściom itp. Duży zasięg powyższych mechanizmów spowodował wprowadzenie na poziomie analiz porównawczych nowych określeń charakteryzujących specyfikę regionu.

Takim określeniem o charakterze systemowym stał się m.in. wprowadzony przez Bank Światowy termin „zawłaszczanie państwa” (state captures). Definiuje on działania jednostek, grup lub firm sektora publicznego bądź prywatnego, które wpływają na tworzenie prawa, regulacji i innych form polityki rządowej dla ich własnych korzyści. Działania te uznaje się za odmianę korupcji wysokiego szczebla będącej rezultatem braku przejrzystości w przepływach prywatnych korzyści do urzędników publicznych ${ }^{27}$.

Niektórzy badacze w odniesieniu do Polski używają pojęcia „częściowego zawłaszczenia państwa” przez sieci interesów, które przejęły od państwa bądź sprywatyzowały niektóre jego funkcje za pomocą agencji lub fundacji opartych na koneksjach politycznych przechwytujących zasoby skarbu państwa ${ }^{28}$. Na podstawie doświadczeń Polski i innych państw postkomunistycznych sformułowali oni koncepcję władzy strukturalnej, która umiejscowiona jest poza konstytucyjnymi organami państwa. Ma ona znajdować się w instytucjach finansowych i gospodarczych, zwłaszcza będących częścią międzynarodowych sieci wielkiego biznesu korporacyjnego ${ }^{29}$. Widoczny jest tu szczególny paradoks, ponieważ profesjonalizm tej sfery biznesu miał w najwyższym stopniu spełniać wymogi merytokratyzmu. Może on jednak służyć innym celom, które dają się charakteryzować w takich kategoriach, jak m.in. narzucenie lokalnym ośrodkom władzy racjonalności odpowiadającej głównie ponadnarodowym instytucjom politycznym i gospodarczym ${ }^{30}$.

Najbardziej radykalną wersję powyższego podejścia prezentuje A. Zybertowicz. Jego zdaniem, różne nieformalne grupy interesów przekształciły proceduralny model demokracji w Polsce w fasadę przesłaniającą dominację zakulisowych podmiotów polityki, np. nieformalnych grup interesu, służb specjalnych lub „oligarchów” wielkiego

27 The World Bank, Anticorruption in Transition. Contribution to the Policy Debate, Washington, D.C. 2000. Zdaniem ekspertów Banku Światowego odpowiednikiem zawłaszczania państwa na poziomie wykonawczym, stosowania istniejącego prawa, zasad i regulacji jest pojęcie „korupcji administracyjnej”.

28 J.R. Wedel, Collision and Collusion. The Strange Case of Western Aid to Eastern Europe, Palgrave, New York 2007, charakteryzuje zasadnicze podobieństwa i różnice pomiędzy typem państwa „częściowo zawłaszczonego” (jak Polska) oraz „państwa klanowego” (Rosja, Ukraina).

29 J. Staniszkis, Władza globalizacji, Wydawnictwo Naukowe Scholar, Warszawa 2003.

${ }^{30} \mathrm{Z}$ perspektywy amerykańskiej sposoby realizacji takich strategii w odniesieniu do Europy Wschodniej i Rosji charakteryzują m.in. J.R. Wedel, Collision..., op.cit.; J. Stiglitz, Globalizacja, Wydawnictwo Naukowe PWN, Warszawa 2004. 
biznesu $^{31}$. Jako dowód występowania takich mechanizmów traktuje zwłaszcza niewyjaśnione tzw. afery gospodarcze na styku polityki i biznesu.

Niezależnie od trafności przywoływanych koncepcji, których analiza wykracza poza cele tego opracowania, większość z nich zwraca uwagę na to, iż mechanizmy zarządzania merytokratycznego w instytucjach publicznych w Polsce są znacząco zredukowane z uwagi na oddziaływanie wielu zjawisk i mechanizmów o negatywnym charakterze. Wyrażają je przywołane powyżej pojęcia - zawłaszczanie państwa, instytucjonalny nomadyzm elit, kapitalizm polityczny, miękkie państwo i instytucjonalizacja nieodpowiedzialności lub zakulisowi aktorzy polityki.

Tego rodzaju zjawiska stały się bardzo znaczące w schyłkowym okresie poprzedniego ustroju, ale przeniosły się także w lata 90 . XX w. i po roku 2000. Wpływały one na matrycę interesów, kluczowych aktorów i standardy instytucjonalne, a także w znacznej mierze na kolejne fazy reform ustrojowych, zwłaszcza w tych obszarach decyzji, w których trudno jest wskazać ostre granice pomiędzy tym, co formalne i nieformalne bądź jawne i niejawne. Wymownym przykładem znaczenia tego rodzaju mechanizmów stała się jesienią 2009 r. „,afera hazardowa”. Ujawniła ona dużą „otwartość" niektórych czołowych polityków PO (w tym jej skarbnika i szefa klubu parlamentarnego) na kontakty z przedsiębiorcami, wśród których znajdowały się osoby skazane wyrokami sądu za korupcję.

Z kolei „afera podsłuchowa”, ujawniająca treści rozmów polityków i urzędników państwowych wysokiego szczebla, wskazała na słabość przestrzegania prawa, jak i dostarczyła kolejnego przykładu zawłaszczania instytucji państwowych. Doszło do wykorzystywania przez kierownictwo Agencji Bezpieczeństwa Wewnętrznego materiałów z urzędowych czynności operacyjnych w prywatnych sprawach sądowych. Natomiast tempo i zakres zmian kadrowych przeprowadzanych przez nowy rząd Prawa i Sprawiedliwości w administracji rządowej i spółkach skarbu państwa od końca 2015 r. po raz kolejny wymuszają postawienie pytań o ich przesłanki oraz konsekwencje w sferze jakości zarządzania instytucjami państwa. Sposób przeprowadzenia tych zmian wzbudza bowiem podnoszone przez media wątpliwości, które dotyczą kryteriów naboru nowych kadr oraz jakości ich profesjonalnego przygotowania do zajmowania obsadzanych stanowisk (negatywnymi przykładami stały się m.in. dymisja nowego komendanta głównego policji po dwóch miesiącach sprawowania tego stanowiska, szybka dymisja nowego szefa PKP i dyskusje wokół nominacji

31 A. Zybertowicz, Demokracja jako fasada: przypadek III RP, w: Utracona dynamika? O niedojrzałości polskiej demokracji, red. E. Mokrzycki, A. Rychard, A. Zybertowicz, Wydawnictwo IFiS PAN, Warszawa 2002; A. Zybertowicz, Przemoc „układu”. O peerelowskich korzeniach sieci biznesowej Zygmunta Solorza, w: Transformacja podszyta przemoca. O nieformalnych mechanizmach przemian instytucjonalnych, red. R. Sojak, A. Zybertowicz, Uniwersytet Mikołaja Kopernika, Toruń 2008. 
niespełniających żadnych kryteriów profesjonalnych współpracowników ministra obrony do rad nadzorczych w koncernach zbrojeniowych).

\section{Systemowe ograniczenia merytokratyzmu}

Poniżej chciałbym rozwinąć i udokumentować tezę głoszącą siłę oddziaływania czynników, które ograniczają zakres merytokratyzmu w instytucjach publicznych, co stanowi jednocześnie jedną z zasadniczych przyczyn niskiej legitymizacji nowego ustroju Polski. W tym celu proponuję posłużenie się schematem analitycznym nawiązującym do koncepcji D. Beethama przyjmującego założenie, że system polityczny jest legitymizowany na kilku poziomach. Autor wskazuje wybrane wyróżniki działalności instytucji publicznych mieszczące się w trzech wymiarach, które wpływają na zakres legitymizacji władzy:

- dominujące reguły (formalne i nieformalne),

- przekonania związane z akceptacją reguł systemu władzy wśród rządzących i rządzonych oraz

- zachowania wyrażające przyzwolenie rządzących na zależności władcze.

\section{Reguły}

Od przyjęcia nowej konstytucji Polski w 1997 r. formalne reguły nie budziły w głównym nurcie debaty politycznej większych kontrowersji i stały się podstawą funkcjonowania systemu politycznego ${ }^{32}$. Wprowadzone zostały procedury wyborcze, których legalność potwierdzają komisje wyborcze, sądownictwo, politycy, media i opinia publiczna ${ }^{33}$. Wątpliwości budziły przede wszystkim sposoby interpretacji stanowionego prawa, a także nieformalne reguły, które sprawiają, że często dochodzi

32 Najwięcej krytycznych ocen prawomocności władzy i jej kształtu instytucjonalnego z 1997 r. wysuwa część liderów i sympatyków partii prawicowych, wśród których popularna jest teza o zmowie elit biorących udział w negocjacjach Okrągłego Stołu, która miała wpłynąć negatywnie na charakter późniejszych zmian ustrojowych. Zob. A. Dudek, Pierwsze lata III Rzeczypospolitej 1981-2001, Arcana, Kraków 2004. Przyjęcie nowej konstytucji i wejście Polski do UE skonsolidowało ustrój polityczny III RP. Afera Rywina na początku poprzedniej dekady stała się jednak katalizatorem koncepcji zmierzających do zmian ustrojowych określonych w 2005 r. przez liderów PiS jako program budowy IV Rzeczypospolitej.

33 Narastająca krytyka dysfunkcji systemu partyjnego ukształtowanego w Polsce na podstawie proporcjonalnej ordynacji wyborczej zrodziła postulat wprowadzenia jednomandatowych okręgów wyborczych do Sejmu. Dyskutowane są również koncepcje zmian zasad finansowania partii politycznych (J. Zbieranek, Zmiany w systemie prawa wyborczego i finansowanie partii politycznych, w: Demokracja w Polsce 2007-2009, red. Kolarska-Bobińska, J. Kucharczyk, Instytut Spraw Publicznych, Warszawa 2004). 
do zawłaszczania i eksploatacji państwa przez partie polityczne i rozmaite powiązane z nimi grupy interesu. Taka praktyka stała się też jednym z czynników najbardziej ograniczających zakres merytokratyzmu w działalności instytucji publicznych w Polsce. W wymiarze instytucjonalnym A. Grzymała-Busse ${ }^{34}$ określiła ten proces mianem odbudowy „partyjnego Lewiatana” typowego dla demokracji w państwach postkomunistycznych. Wyodrębnia ona trzy jego formy:

1) tworzenie instytucji nadzoru i monitoringu (regulacyjnych, kontrolnych itd.),

2) ekspansję zatrudnienia w administracji państwowej (wzrost agencji i funduszy przechwytujących środki budżetowe) oraz

3) przejmowanie korzyści związanych z prywatyzacją i subsydiami publicznymi.

Tego rodzaju zjawiska ograniczające zakres merytokratyzmu w działalności polskich instytucji ustrojowych przedstawia tabela 1 (uwzgledniająca reguły, przekonania i zachowania). Reguły gry politycznej umożliwiają politykom podporządkowanie instytucji interesom partyjnym. Wykorzystują do tego rozbudowę administracji państwowej i samorządowej ${ }^{35}$. Pomocne w tym okazują się istniejące regulacje dotyczące finansowania polityki (finansowanie z budżetu). Umożliwiają one oficjalne przerzucenie części kosztów działania partii i organizowania kampanii wyborczych na budżet państwa. Rocznie największe partie otrzymują ponad $54 \mathrm{mln} \mathrm{z}^{36}$.

Wiele form partyjnego zawłaszczania państwa obejmuje w znacznej mierze nie tylko sektor publiczny, lecz również inne obszary życia społecznego, zwłaszcza w gospodarce i w sektorze prywatnym. Przykładem może być prywatyzacja przedsiębiorstw, realizacja zamówień publicznych, udzielanie gwarancji kredytowych itp. W rezultacie, jak zauważa V. Bunce w komentarzu do wyników badań nad europejskimi państwami postkomunistycznymi, ,instytucje polityczne stanowią tutaj zwykle jedynie fasadę, prawdziwa polityka rozgrywa się zaś gdzie indziej; instytucje te funkcjonują zwykle wadliwie, brakuje im bowiem wielu zwykle z nimi kojarzonych właściwości, które w krajach zachodnich dostarczają przewidywalnych zachęt kształtujących następnie przewidywalne wzorce zachowań politycznych"37.

${ }^{34}$ A. Grzymała-Busse, Redeeming the Communist Past. The Regeneration of Communist Parties in East Central Europe, Cambridge University Press, Cambridge 2002.

${ }^{35}$ Wzrost zatrudnienia w administracji państwowej po 1989 r. szacuje się wg różnych źródeł w przedziale od 80 do 261\% (A. Grzymała-Busse, Rebuilding Leviathan. Party Competition and State Exploitation in Post-Communist Democracies, Cambridge University Press, Cambridge 2007, s. 238). Rozbudowa administracji wiąże się także z realizacją nowych zadań państwa wynikających m.in. z wymogów akcesji do UE oraz tworzenia instytucji regulujących nowe sfery gospodarki i życia społecznego, np. w dziedzinie prywatyzacji, rynków kapitałowych bądź mediów elektronicznych.

${ }^{36}$ J. Zbieranek, Finansowanie partii politycznych w Polsce - czy i jakie zmiany?, Fundacja im. S. Batorego, 2015, http://www.batory.org.pl/upload/files/Programy\%20operacyjne/PolicyPaper_Finansowanie\%20 partii.pdf, dostęp 12.10.2016.

${ }_{37}$ R. Karklins, Wszystkiemu winien system. Korupcja w krajach postkomunistycznych, Sic!, Warszawa 2009, s. 23. 
Polską egzemplifikacją tej problematyki są permanentne dyskusje o praktykach partyjnego „podziału łupów” w administracji, mediach oraz innych instytucjach sektora publicznego, który obejmuje także urzędy skarbowe i kuratoria oświaty ${ }^{38}$. Obrazują ją kontrowersje wokół częstych zmian ustawowych dotyczących służby cywilnej i obsady stanowisk w administracji rządowej ${ }^{39}$, jak również nominacji do rad nadzorczych i zarządów spółek z udziałem skarbu państwa - mediów publicznych, banków, agencji i fundacji, a nawet organów kontroli państwowej i ochrony prawa, jak Krajowa Rada Radiofonii i Telewizji, bądź ważnych instytucji finansowych (Narodowy Bank Polski, Komisja Nadzoru Finansowego itd.) ${ }^{40}$. Na styku gospodarki i polityki praktyka ta wykazuje klasyczne cechy korupcji politycznej, tworzącej reguły patologicznego „sprzężenia” interesów firm, decydentów partyjnych i administracji państwowej. Osoby kierujące największymi spółkami są bowiem silnie zakorzenione w elitach władzy politycznej, co przekłada się na częste wymiany członków zarządów i rad nadzorczych w zależności od zmian konfiguracji politycznych, zwłaszcza cyklu wyborczego. Tak rządzone firmy zwykle nie są w stanie budować stabilnych strategii rozwojowych, są słabo zarządzane i kontrolowane ${ }^{41}$.

Podlegają również w większym zakresie racjonalności polityki i rozmaitych grup interesu niż wymogom rynku, czego przykładem jest sektor górnictwa węgla

${ }^{38} \mathrm{~W}$ takim kontekście ważnym problemem jest programowa i kadrowa słabość polskich partii politycznych, które w odróżnieniu od partii zachodnich nie stworzyły sieci profesjonalnego zaplecza eksperckiego, np. w postaci silnych think-tanków. Polskie partie polityczne w bardzo niewielkim zakresie wykorzystują też na takie cele subwencje przekazywane z budżetu państwa. Obecny system finansowania polityki nie określa, na jakie cele powinny być wydatkowane środki z budżetu oraz jak powinny być one kontrolowane. Finansowanie partii w takim kształcie wspiera model partii wodzowskich i synekur umożliwiających malwersacje finansowe dotyczące środków publicznych przekazywanych partiom (M. Walecki, J. Zbieranek, Finansowanie polityki, w: Demokracja w Polsce 2005-2007, red. L. Kolarska-Bobińska, J. Kucharczyk, J. Zbieranek, Instytut Spraw Publicznych, Warszawa 2007, s. 93-122).

39 „Polityczne” nominacje na stanowiska kierownicze i częste zmiany kadrowe podważające stabilność pracy urzędów powodowały, że niektórzy badacze uznawali za „wyspy profesjonalizmu” w administracji rządowej głównie instytucje związane z Unią Europejską (było to Ministerstwo Rozwoju i Urząd Komitetu Integracji Europejskiej). Równocześnie podkreślali, że „upolitycznienie” może być także zjawiskiem pozytywnym, jeśli wiązałoby się z pozyskaniem wiedzy specjalistycznej i zarządzania informacją. W sprawie zakresu upolitycznienia administracji rządowej w Polsce, zmian legislacyjnych i praktyki ich stosowania zob. P. Heywood, J.-H. Meyer-Sahling, Występowanie stref korupcji w zarządzaniu polską administracja rząowa, Sprawne Państwo Program Ernst \& Young, Warszawa 2008; A. Kamiński, Polityczne uwarunkowania sprawności administracji publicznej: przypadek pokomunistycznej Polski, w: Materiały konferencji W drodze do demokratycznego państwa prawa. Polska 1989-2009, Rzecznik Praw Obywatelskich, Warszawa 2009.

40 Niektóre szacunki przyjmują, że w samych organach spółek skarbu państwa sprawujące władzę elity polityczne dysponują 30 tys. intratnych stanowisk, które przekładają się również na wpływ dotyczący strategicznych decyzji biznesowych w gospodarce (P.R. Ruszkowski, Dysfunkcjonalne grupy interesów a system społeczny, w: Szara strefa przemocy - szara strefa transformacji? Przestrzenie przymusu, red. R. Sojak, Uniwersytet Mikołaja Kopernika, Toruń 2007, s. 115-144).

${ }^{41}$ M. Jarosz, Władza. Przywileje. Korupcja, WN PWN - ISP PAN, Warszawa 2004. 
kamiennego ${ }^{42}$.Z perspektywy orientacji merytokratycznych duże zastrzeżenia budzą polityczne mechanizmy selekcji rządzących, w tym obecność na listach partyjnych w wyborach na wszystkich poziomach kandydatów mało kompetentnych, nierzadko skompromitowanych, m.in. znajdujących się w konflikcie z prawem. Skutkuje to często niską jakością „,klasy politycznej”, miałkością oferty programowej partii politycznych, nieumiejętnością konsolidacji społeczeństwa wokół celów polityki państwa.

Od dawna widoczny jest żenująco niski poziom wypowiedzi i refleksji ${ }^{43}$, który przekłada się na kłopoty $\mathrm{z}$ formułowaniem dokumentów strategicznych. W znanym raporcie, który powstał pod redakcją J. Hausnera pt. Kurs na innowacje jest mowa o „zaniku suwerennej strategicznej myśli rozwojowej” ${ }^{\text {*4 }}$. Autorzy stawiają tezę o słabości ośrodków myślenia i projektowania strategicznego w instytucjach państwa.

Kolejnym wymiarem funkcjonowania państwa, w którym wyraźna jest słabość orientacji merytokratycznej, jest administracja publiczna. Nadal funkcjonuje ona w kulturze tajności, a władzę definiuje się raczej w kategoriach przywilejów niż odpowiedzialności. Badacze porównujący polską administrację publiczną z administracją w krajach UE posługują się określeniem „funkcjonalnego dualizmu”, tj. aktywności ceremonialnej, która ze względu na wymogi członkostwa w Unii tworzy instytucje analogiczne do zachodnich, lecz ich działalność nie przynosi spodziewanych rezultatów ${ }^{45}$.

W raporcie ekspertów rządu Polska 2030 (ze wstępem premiera Donalda Tuska), czytamy: „w polskiej administracji publicznej nadal dominuje Weberowski model silnie zhierarchizowanej administracji i rzadkiego delegowania kompetencji. Efektem jest niska skuteczność działania, przedłużające się procedury, trudności we wprowadzaniu nowoczesnych narzędzi zarządzania zasobami ludzkimi i systemów premiowych" ${ }^{\prime 6}$.

42 K. Gadowska, Zjawisko klientelizmu polityczno-ekonomicznego. Systemowa analiza powiązań sieciowych na przykładzie przekształceń sektora górniczego w Polsce, Uniwersytet Jagielloński, Kraków 2002. W kwestii jakości zarządzania spółek z udziałem skarbu państwa na tle innych grup podmiotów gospodarczych zob. K. Jasiecki, Kapitalizm po polsku..., op.cit., s. 238-257.

${ }_{43}$ M. Grabowska, dyrektor CBOS zauważyła, że „w Polsce od lat nie dokonuje się pozytywna selekcja do polityki. Partie polityczne mają zszarganą opinię. Są postrzegane jako grupy ludzi zajmujące się załatwianiem różnych spraw dla siebie i swoich środowisk” (cyt. za K. Baranowska, Wyborcy potrzebuja czasu. Wywiad z Mirosława Grabowska, „Rzeczpospolita”, 27 października 2009). Jak odnotował jeden z dziennikarzy, „polską polityką rządzi banał. [...] Kiedy się rozmawia z politykami, w tym najważniejszymi, zawstydza to, że oni niczego wartościowego nie czytają. [...] nie ćwiczą swoich umysłów w myśleniu strategicznym czy choćby logicznym” (S. Janecki, Analfabeci polityki, „Wprost”, 21 czerwca 2009).

44 T. Geodecki, G. Gorzelak, J. Górniak, J. Hausner, S. Mazur, J. Szlachta, J. Zaleski, Kurs na innowacje. Jak wyprowadzić Polskę z rozwojowego dryfu, Fundacja Gospodarki i Administracji Publicznej, Warszawa 2012.

45 S. Mandes, Doświadczenie urzędników administracji publicznej we współpracy z partnerami zachodnimi, w: Kulturowe aspekty transformacji ekonomicznej, red. J. Kochanowicz, S. Mandes, M. Marody, Instytut Spraw Publicznych, Warszawa 2007, s. 178-179.

46 Polska 2030. Wyzwania rozwojowe, red. M. Boni, Zespół Doradców Strategicznych Prezesa Rady Ministrów, Warszawa 2009, s. 308. 
W charakterystyce tego modelu podkreślana jest m.in. anachroniczność systemu wynagradzania, niewiążąca wysokości wynagrodzenia z realizacją przyjętych celów działania (która bardzo utrudnia pozyskiwanie wysoko wykwalifikowanych kadr na wyższe stanowiska specjalistyczne lub menedżerskie), brak systemu nowoczesnych mechanizmów oceny i kontroli wewnętrznej oraz niska orientacja na wyniki.

Mamy zatem do czynienia z potwierdzonym urzędowo marnotrawstwem kapitału ludzkiego sprzecznym z zasadami merytokracji. Do analogicznych wniosków prowadzą badania M. Kwiatkowskiego zawarte w książce pt. Nieprzejrzystość. Bariery merytokracji kadrowej w sektorze publicznym ${ }^{47}$. Autor w innym tekście pisze, że przywiązanie do idei merytokracji jest „deklarowane głównie w dyskursie uroczystym, natomiast w innych typach dyskursu (polemiczny, nieoficjalny) na pierwszy plan wysuwają się inne kryteria (zaufanie, lojalność, przynależność)" ${ }^{\prime 4}$. Pomimo deklaracji składanych zwykle w okresie kampanii wyborczych kolejne zmiany rządów nie wnoszą w tym zakresie wartości dodanej.

Warto wskazać na kolejne reguły ograniczające zakres merytokratyzmu w działalności instytucji państwa. Na uwagę zasługują ułomne procedury powszechnej reprezentacji politycznej. Wskaźnikiem ich występowania jest słabość lub kryzys dialogu społecznego i asymetryczność reprezentacji interesów, która preferuje niektóre branże gospodarki i wielkie przedsiębiorstwa państwowe bądź dobrze zorganizowane politycznie grupy zawodowe.

Wśród decydentów politycznych występuje, jak w zakresie programowania rozwoju społeczno-gospodarczego, niewielkie zrozumienie dla idei oraz praktyki dialogu społecznego. Organizacje pracodawców, związki zawodowe, a także sektor innych organizacji pożytku publicznego od kilku lat postulują wzmocnienie ustrojowej rangi dialogu społecznego i obywatelskiego oraz równoprawnego traktowania partnerów społecznych.

W 2013 r. doszło do zawieszenia działalności związków zawodowych w Trójstronnej Komisji do spraw Społeczno-Gospodarczych. Oznaczało to w praktyce zakwestionowanie nowych zasad funkcjonowania instytucjonalnych form dialogu społecznego kształtowanych w Polsce od lat 90. XX w. W miejsce Trójstronnej Komisji powołano jesienią 2015 r. Radę Dialogu Społecznego, która ma tę samą strukturę członkostwa, ale nieco większe uprawnienia w procesie stanowienia prawa ${ }^{49}$. Pierwsze sygnały o jej

${ }^{47}$ M. Kwiatkowski, Nieprzejrzystość. Bariery merytokracji kadrowej w sektorze publicznym, Oficyna Wydawnicza Uniwersytetu Zielonogórskiego, Zielona Góra 2011.

${ }^{48}$ M. Kwiatkowski, Dlaczego obawiamy się merytokracji kadrowej? Spojrzenie socjologa, „Przegląd Służby Cywilnej”, Departament Służby Cywilnej Kancelarii Prezesa Rady Ministrów, październik 2014, s. 20.

${ }^{49}$ Szerzej zob. Polska $w$ dialogu. Tradycja, zmiany, porównanie perspektywy, red. A. Zybała, CPS „Dialog”, Warszawa 2016. 
funkcjonowaniu wskazują, że RDS może również nie spełniać oczekiwań partnerów społecznych, przybierając w kolejnej wersji instytucjonalizacji dialogu społecznego charakter fasadowy ${ }^{50}$.

Przykładami potwierdzającymi taką tezę mogą być m.in. procedury prac w Sejmie nad projektem ustawy ograniczającej handel w niedzielę, pomijające RDS (chociaż projekt został wniesiony przez Komitet Inicjatywy Ustawodawczej z działaczami NSZZ „Solidarność” na czele, a w tym czasie przewodniczącym RDS był lider Solidarności) ${ }^{51}$, protesty nauczycieli przeciwko rządowym planom reformy oświaty i szkolnictwa lub pracowników służb medycznych domagających się uwzględnienia ich postulatów dotyczących warunków pracy i wynagrodzenia ${ }^{52}$.

\section{Przekonania}

Wzory dominujących postaw i przekonań odbiegają w Polsce znacząco od postulatów merytokratyzmu. Ma to źródło w odtwarzaniu wzorów zachowań, które wywodzą się z romantycznej i postromantycznej kultury politycznej oraz doświadczeń okresu rządów komunistycznych, jak również sposobów reformowania państwa po 1989 r. W Polsce ze względów historycznych nazbyt często przeważa potępienie lub marginalizowanie orientacji pragmatycznych, nastawionych na działanie kooperacyjne i osiąganie kompromisów. Długotrwała utrata suwerennego państwa polskiego i walka o niepodległość powodowały, że skłonność do negocjacji z przeciwnikami politycznymi była często pojmowana w kategoriach zdrady. Podziały polityczne i ideologiczne definiowane według zachodnich kryteriów były wyciszane, by nie przesłaniały naczelnego celu, tj. walki o niepodległość.

Analogiczne podejście przeważało wewnątrz opozycji antykomunistycznej po II wojnie światowej. W początkowym okresie „wychodzenia z komunizmu” najbardziej nośne wzorce osobowe tworzyli inteligenci i działacze związkowi, których głównym walorem była postawa ideowa i walka $\mathrm{z}$ ustrojem komunistycznym, a nie przygotowanie merytoryczne lub kwalifikacje zarządcze, które system monopolizował dla swoich zwolenników. W Polsce, jak w innych państwach Europy Środkowej i Wschodniej, w okresie władzy komunistycznej ukształtował się wzorzec rządzenia

\footnotetext{
${ }^{50}$ Dyskusję na temat fasadowości dialogu społecznego przedstawiam w pracy K. Jasiecki, Kapitalizm po polsku..., op.cit., s. 325-345.

${ }^{51} \mathrm{http}: / /$ orka.sejm.gov.pl/Druki8ka.nsf/0/65031EB21E0B978CC1258036005797DE/\%24File/870.pdf

52 Przyczyny załamania się dialogu społecznego w $2013 \mathrm{r}$., genezę i przebieg prac nad ustawą o RDS, a także oczekiwania związane z jej powstaniem charakteryzuje A. Grabowska, Reforma dialogu społecznego w Polsce. Od zawieszenia do nowej formuły trójstronnej debaty, Fundacja im. Friedricha Eberta, Warszawa 2016.
} 
nomenklaturowego, który w zmodyfikowanej wersji stał się częścią kultury politycznej także nowego aparatu władzy ${ }^{53}$. Jak zauważył szef Urzędu Służby Cywilnej, „dawną nomenklaturę monopartyjną zastąpił system multinomenklatury, w którym każda partia stara się objąć pewną pulę stanowisk" ${ }^{54}$.

W rezultacie, chociaż logika transformacji otworzyła rosnącą przestrzeń dla orientacji merytokratycznej (zwłaszcza w sektorze prywatnym) ${ }^{55}$, to w instytucjach publicznych szczególną rolę odgrywały podziały biograficzne i środowiskowe, związane z charakterem działalności politycznej prowadzonej w schyłkowym okresie PRL. W latach 90. XX w. kryteria te zinstytucjonalizowały się w postaci makropolitycznego podziału na obóz postsolidarnościowy i obóz postkomunistyczny ${ }^{56}$. Z kolei od 2005 r. doszło do ukształtowania się analogicznego podziału na obóz Platformy Obywatelskiej oraz Prawa i Sprawiedliwości. Rywalizacja polityczna między tymi obozami zyskała taki charakter, że nadała nowe znaczenia zasadzie „nagradzania według zasług” i rządów „najlepiej przygotowanych”. Walka o władzę legitymizowana ogólnikowymi hasłami ideologicznymi zaczęła bowiem coraz częściej uzasadniać praktyki traktowania instytucji państwa w kategoriach „republiki kolesiów” stanowiącej domenę rządzących partii politycznych ${ }^{57}$.

Powyższe zjawiska dobrze opisywali od wielu lat sami politycy tworzący zasady i praktykę ich implementacji. Na przykład J. Kaczyński uznał, że w obozie Akcji Wyborczej Solidarność panowała reguła „TKM” („Teraz, k..., my!”). Znamienny był także esemes A. Halbera, przedstawiciela Sojuszu Lewicy Demokratycznej w Krajowej Radzie Radiofonii i Telewizji - „Chwała nam i naszym kolegom, ch... precz”. Powyższe formuły obrazowały faktyczne kryteria obsadzania stanowisk przez zmieniające się koalicje. Rządziły one według tzw. zasady BMW - „bierny, mierny, ale wierny”. Są one interpretowane w kategoriach klientelizmu indywidualnego i masowego, który

53 A. Grzymała-Busse, Redeeming the Communist Past..., op.cit; A. Grzymała-Busse, Rebuilding Leviathan..., op.cit.

54 J. Pastwa, Wypowiedź dla „Wprost”, 1 kwietnia 2001, s. 31.

${ }_{55}$ M. Grabowska, Podział postkomunistyczny. Społeczne podstawy polityki w Polsce po 1989 roku, Wydawnictwo Naukowe Scholar, Warszawa 2004. Zob. typologię ścieżek prowadzących do kariery w nowej elicie polskiego biznesu: K. Jasiecki, Elita biznesu w Polsce, IFiS PAN, Warszawa 2002.

${ }^{56}$ M. Grabowska, Podział postkomunistyczny..., op.cit. W konkluzji badań w Sejmie odnotowałem niegdyś, że kształtujący się w Polsce konsens można określić jako relatywnie „wąski” problemowo (dotyczący głównie deklaratywnej akceptacji instytucji demokratycznych oraz zbliżenia do NATO i UE) oraz „płytki” ze względu na ostrość podziałów politycznych wśród elit władzy. Wyniki badania potwierdzały występowanie „syndromu niezgodliwości” w polskiej polityce wskazującego, że znaczące rozbieżności w kwestiach ustrojowych i społecznych w Polsce mają charakter strategiczny, a nie taktyczny. K. Jasiecki. Konsens i konflikt w poglądach elity politycznej, w: Polityka i sejm: formowanie się elity politycznej, red. W. Wesołowski, B. Post, Wydawnictwo Sejmowe, Warszawa 1998, s. 83-84.

57 Problem roli „kolesiostwa” w polityce spopularyzował politolog R. de Jouvenel w satyrze na praktyki polityczne IV Republiki Francuskiej: La Republiques des Camerades, 1993. 
jest analizowany w badaniach układów nieformalnych, w tym sieciowych, uwzględniających zależności wertykalne typu patron-klient, jak również horyzontalne, tj. cronyism, kolesiostwo lub kumoterstwo ${ }^{58}$.

Dwie kadencje rządów Platformy Obywatelskiej i Polskiego Stronnictwa Ludowego utrwaliły tę sytuację, co zdają się potwierdzać m.in. kontrowersje wokół reprywatyzacji w Warszawie lub wiele tzw. afer gospodarczych (upadek Amber Gold, infoafera, afera hazardowa itd.). Nieprzypadkowo badacze zespołu Polskich Badań Panelowych POLPAN odnotowują: "Analizy danych sondażowych wskazują, że zaufanie do instytucji państwowych w Polsce jest jednym z najniższych w Europie - jest niższe niż w większości państw Europy Zachodniej i zaledwie przeciętne wśród krajów postkomunistycznych" ${ }^{\text {9 }}$.

Przejęcie władzy przez PiS po zwycięskich wyborach prezydenckich i parlamentarnych w $2015 \mathrm{r}$. wiąże się z „rewolucją kadrową”, która jest uzasadniana przekonaniem, że realizacja polityki nowego rządu wymaga radykalnych zmian personalnych niezbędnych dla jej efektywności. Zdaniem przedstawicieli organizacji pracodawców, zmiany kadrowe $\mathrm{w}$ administracji mogą usprawnić jej działania. Jednak ponieważ zniesiono konkursy na wyższe stanowiska, trudno ocenić, w jakiej mierze nowe kadry są merytorycznie kompetentne bądź są to przede wszystkim nominacje polityczne. Zwraca się również uwagę na to, że duży zakres zmian kadrowych podważa utrwalone ścieżki karier urzędniczych, co działa w administracji demotywująco ${ }^{60}$. Odwołanie z rządu ministra skarbu i uruchomienie procedur kontroli zasadności podejmowanych przez niego decyzji kadrowych w spółkach skarbu państwa, jak też dyskusje wokół osób mianowanych do rad nadzorczych przedsiębiorstw z sektora zbrojeniowego, sugerują, że kryteria kompetencyjne nie były w tych sprawach kluczowe.

\section{Zachowania}

Wzorce zachowań w sferze publicznej również ograniczają zakres merytokratyzmu w instytucjach publicznych. Na szczególną uwagę zasługuje styl sprawowania władzy dominujący w tych instytucjach, wpływ grup interesu na standardy przeważające

58 K. Gadowska, Przemoc w przestrzeni sieci klientelistycznych i kolesiowskich, w: Szara strefa przemocy - szara strefa transformacji? Przestrzenie przymusu, red. R. Sojak, UMK, Toruń 2007, s. 148-149; J. Wedel, Klany, kliki i zawłaszczone państwo. O przedefiniowaniu „przejścia” w Europie Środkowo-Wschodniej i dawnych republikach Związku Radzieckiego, w: Szara strefa przemocy - szara strefa transformacji? Przestrzenie przymusu, red. R. Sojak, Uniwersytet Mikołaja Kopernika, Toruń 2007.

59 POLPAN, Zaufanie do instytucji państwowych, IFiS PAN, Warszawa 2015, s. 8-9.

60 Według mediów ministrowie PiS wymienili wiosną ok. 40 proc. dyrektorów w urzędach administracji państwowej. Zob. A. Cieślak-Wróblewska, Połowiczne czystki resortowe, „Rzeczpospolita”, 4 maja 2016. 
w sferze publicznej, zjawiska korupcji politycznej i administracyjnej oraz wyobcowanie „klasy politycznej”. Wspomniany wcześniej konfrontacyjny styl sprawowania władzy i administrowania państwem dominujący w ostatnich latach w Polsce został przeniesiony także $\mathrm{w}$ obszar dialogu społecznego, stając się istotną przyczyną jego kryzysu, jak również nadmiernie upartyjnił dyskurs publiczny i proces decyzji politycznych. Badacze orientacji aksjologicznych podkreślają, że w polskiej działalności politycznej od lat przeważa Weberowska etyka przekonań, akcentująca ideologiczne aspekty polityki, w odróżnieniu od przeważającego do niedawna w państwach ugruntowanej demokracji podejścia opartego na etyce odpowiedzialności, bazującej na pragmatyzmie w zarządzaniu polityką publiczną ${ }^{61}$.

Wskaźnikiem występowania tego zjawiska była kooperacja negatywna między głównymi ośrodkami władzy państwowej w latach 2007-2010, a także relacje pomiędzy głównymi partiami politycznymi i ich liderami także w późniejszym okresie. Taki styl komunikacji politycznej był wyraźnie widoczny i jest nadal obecny w wielu wymiarach polityki państwa - począwszy od polityki zagranicznej (kwestia podmiotowości kraju), oceny historii (kontrowersje wokół postaci Lecha Wałęsy, rocznic powstania Solidarności, rozmów Okrągłego Stołu itd.), przez interpretację reguł prawnych (spór wokół aktywizmu prawniczego, prawa naturalnego), radykalnie odmienne oceny polityki gospodarczej (planu Balcerowicza, znaczenia prywatyzacji, roli państwa, kapitału zagranicznego), aż do poziomu konfliktów wokół nominacji dyplomatycznych, generalskich i sędziowskich.

Do rangi symbolu urosły konflikty pomiędzy prezydentem Lechem Kaczyńskim i premierem Donaldem Tuskiem o dysponowanie rządowym samolotem w delegacji na szczyt UE w Brukseli lub publiczne debaty dotyczące zachowań prezydenta Kaczyńskiego podczas wojny gruzińsko-rosyjskiej w $2008 \mathrm{r}$. (polecenie lądowania samolotu z prezydentem na pokładzie). Konflikt ten miał również znaczący wpływ na okoliczności katastrofy lotniczej pod Smoleńskiem w 2010 r. Zorganizowano bowiem dwie odrębne wizyty przedstawicieli polskich władz na uroczystości w Katyniu. Samolot z prezydentem Kaczyńskim i 95 innymi osobami na pokładzie rozbił się podczas lądowania. Tragedia ta, wraz z towarzyszącymi jej okolicznościami (pogrzebami ofiar katastrofy, konfliktem wokół krzyża na Krakowskim Przedmieściu, oceną raportu komisji Millera, organizacją miesięcznic smoleńskich itd.), stała się przesłanką nowego sporu politycznego i ideologicznego głęboko dzielącego społeczeństwo polskie, który dalece wykracza poza standardy merytokratyzmu. W sporze tym kwestionowane są także autorytety naukowe, a język i używana argumentacja mają

61 A. Jasińska-Kania, Orientacje aksjologiczne Polaków na tle europejskim, w: Oswajanie wielkiej zmiany, red. I. Krzemiński, J. Raciborski, Instytut Socjologii UW, Warszawa 2007, s. 336. 
przede wszystkim charakter emocjonalny, używający rozmaitych faktów w sposób skrajnie instrumentalny i demagogiczny.

Zachowania głównych aktorów sceny politycznej generują wciąż nowe problemy polityczne i ustrojowe, czego przykładem jest kryzys konstytucyjny zarysowany w końcu 2015 r., który przeniesiony został także na forum unijne (debaty w Parlamencie Europejskim, opinie Komisji Weneckiej). Są to okoliczności, w których głównym instytucjom państwa niesłychanie trudno jest wytworzyć wspólne ramy polityki wobec wyzwań globalnego kryzysu finansowego i gospodarczego, kryzysu politycznego i instytucjonalnego UE lub kryzysu migracyjnego. Powyższe zjawiska i tendencje w znacznej mierze stanowią również konsekwencje dotarcia do Polski mechanizmów tzw. postpolityki, związanych z mediatyzacją działalności politycznej.

Współcześnie prowadzi ona do koncentrowania się kluczowych polityków raczej na public relations i marketingu politycznym niż na substancjalnej zawartości polityki. Równocześnie konfliktowe oraz skrajne upartyjnienie dyskursu publicznego i decyzji politycznych utrudnia identyfikację obywateli z symbolami i instytucjami władzy. Sugeruje bowiem ich afiliacje do głównych obozów politycznych, które nie wyczerpują preferencji politycznych Polaków i zniechęcają wielu z nich do uczestnictwa w działalności publicznej realizowanej w takich okolicznościach. W środowiskach akademickich na przykład pojawiają się postawy nawiązujące do „emigracji wewnętrznej" znanej z lat 80. XX w.

Innym czynnikiem ograniczającym zakres merytokratyzmu w instytucjach ustrojowych jest działalność rozmaitych grup wpływu narzucających partykularne standardy w sferze publicznej. Grupy te (o różnym stopniu instytucjonalizacji), posługują się wieloma strategiami i metodami oddziaływań - klientelistycznymi, korporatywistycznymi, syndykalistycznymi, opartymi na nepotyzmie, „kolesiostwie” itd. Ich wspólnym mianownikiem jest często „wypaczona wizja dobra publicznego” ${ }^{2}$, która - m.in. ze względu na słabość państwa - sprzyja zawłaszczaniu jego instytucji na swoje potrzeby.

Rozwój grup wpływu z jednej strony jest integralnym składnikiem społeczeństwa obywatelskiego, jak np. organizacje samorządu zawodowego. Równocześnie jednak wiele z nich tworzy korporacyjne bądź towarzysko-protekcyjne grupy wpływu, które wraz z częścią działaczy partyjnych i urzędników państwowych stają się elementem swoistych „koalicji redystrybucyjnych” realizujących swoje preferencje z pogwałceniem interesu publicznego, a nierzadko także reguł prawa i zasad moralnych ${ }^{63}$. Najbardziej

62 R. Karklins, op.cit., s. 164.

${ }^{63}$ A. Kamiński, Polityczne uwarunkowania sprawności administracji publicznej..., op.cit.; P.R. Ruszkowski, op.cit.; K. Jasiecki, M. Molęda-Zdziech, J. Kurczewska, op.cit.; M. Jarosz, op.cit.; K. Burnetko, O demokracji w administracji publicznej, w: Demokracja w Polsce 2007-2009, red. L. Kolarska-Bobińska, J. Kucharczyk, Instytut Spraw Publicznych, Warszawa 2009; K. Gadowska, Przemoc w przestrzeni sieci 
negatywne aspekty oddziaływania takich koalicji w polskich instytucjach publicznych charakteryzuje znacząca korupcja polityczna i administracyjna. Wskaźnikiem jej rozpowszechnienia jest duża częstotliwość oskarżeń związanych z nadużywaniem władzy dla prywatnych korzyści, która w ostatnich latach stała się przedmiotem wielu badań i raportów.

Z perspektywy regionalnego rozkładu wskaźników korupcji Polska (jak państwa Europy Środkowej i kraje nadbałtyckie) wyróżnia się mniejszym natężeniem tego zjawiska niż państwa Europy Południowo-Wschodniej, a zwłaszcza kraje należące do Wspólnoty Niepodległych Państw ${ }^{64}$. Jednak na tle państw wysoko rozwiniętych jest ono na tyle duże, że jak zauważano dekadę wcześniej, stanowi symptom instytucjonalnej niewydolności państwa, a nawet zagrożenia dla rozwoju polityczno-gospodarczego kraju ${ }^{65}$.

Jeśli przyjąć, że istnieje „uderzająca korelacja” pomiędzy wskaźnikiem korupcji w Polsce a negatywnymi prawidłowościami zarządzania w administracji rządowej ${ }^{66}$, to analogiczna zależność dotyczy również merytokracji. Znaczące wskaźniki korupcji stanowią bowiem pośredni miernik roli i znaczenia odmiennych niż merytokratyczne wzorów zachowań, motywacji jednostek i mechanizmów działania instytucji publicznych. Wskazują one także na znaczenie nawyków wyniesionych z poprzedniego ustroju, jak również nowych postaci nieformalnych działań i struktur, w tym powiązań opierających się na protekcji oraz wymianie przysług, występujących zarówno na poziomie elit, jak i ogółu obywateli.

Jednym z następstw powszechnego charakteru takich zachowań jest znaczące wyobcowanie polskiej „klasy politycznej”, które ogranicza jej zdolność do mobilizowania obywateli na rzecz realizacji celów publicznych. Standardowym wskaźnikiem występowania tego zjawiska jest partycypacja wyborcza mierzona udziałem obywateli w wyborach parlamentarnych. W Polsce średnia frekwencja we wszystkich wyborach parlamentarnych po 1989 r. jest najniższa ze wszystkich krajów postkomunistycznych będących obecnie członkami UE. Wynosi ona mniej niż 50 proc., podczas gdy średnia frekwencja dla większości tej grupy państw oscyluje wokół 60-70 proc ${ }^{67}$.

klientelistycznych i kolesiowskich..., op.cit.; K. Gadowska, Zjawisko klientelizmu polityczno-ekonomicznego..., op.cit.

${ }^{64}$ Znakomitą, wielowymiarową, obszerną analizę problematyki korupcji w społeczeństwach postkomunistycznych, wraz z typologią tego zjawiska, analizą postaw, rolą instytucji i rekomendacjami dotyczącymi strategii antykorupcyjnych zob. R. Karklins, op.cit.

${ }_{65}$ A. Kamiński, Korupcja jako symptom instytucjonalnej niewydolności państwa i zagrożenie dla rozwoju polityczno-gospodarczego Polski, w: Dobro wspólne, władza, korupcja, red. E. Popławska, Instytut Spraw Publicznych, Warszawa 1997.

${ }^{66}$ P. Heywood, J.-H. Meyer-Sahling, op.cit., s. 77.

${ }^{67}$ H. Domański, A. Pokropek, T. Żółtak, Stratyfikacja społeczna a zachowania polityczne. Kraje europejskie w latach 2002-2012, IFiS PAN, Warszawa 2015. W sprawie statystyk frekwencji w wyborach powszechnych (parlamentarnych i prezydenckich) na całym świecie w latach 1945-2006 zob. Aktywizowanie 
W ostatnich wyborach parlamentarnych w $2015 \mathrm{r}$. frekwencja była nieznacznie większa - 50,92 proc. Taki wynik jest przejawem niskiej społecznej legitymizacji ustroju III Rzeczypospolitej, jak również słabego zakorzenienia wprowadzonych w Polsce rozwiązań instytucjonalnych ${ }^{68}$.

Tabela 1. Czynniki ograniczające zakres merytokratyzmu w Polsce

\begin{tabular}{|c|c|c|}
\hline $\begin{array}{c}\text { Wymiary } \\
\text { analizy }\end{array}$ & Wyróżniki działalności instytucji ustrojowych & Wskaźniki występowania \\
\hline Reguły & $\begin{array}{l}\text { - zawłaszczanie i eksploatacja państwa przez } \\
\text { partie polityczne } \\
\text { - wadliwe mechanizmy selekcji rządzących } \\
\text { - przestarzały model funkcjonowania } \\
\text { administracji publicznej } \\
\text { - niska jakość regulacji } \\
\text { - słabość rządów prawa } \\
\text { - ułomne procedury reprezentacji politycznej }\end{array}$ & $\begin{array}{l}\text { - zakres „podziału łupów” w sektorze publicznym } \\
\text { - niska jakość „klasy politycznej” } \\
\text { - niska skuteczność działania, słabość, } \\
\text { niestabilność administracji i służby cywilnej } \\
\text { - długotrwale, kosztowne, skomplikowane } \\
\text { i nieprzejrzyste procedury } \\
\text { - instrumentalne wykorzystywanie prawa } \\
\text { - niewłaściwy system stanowienia prawa } \\
\text { - nadmiernie obszerne, niestabilne i przesadnie } \\
\text { szczegółowe prawo } \\
\text { - wadliwa egzekucja prawa } \\
\text { - kryzys dialogu społecznego } \\
\text { - asymetryczność reprezentacji interesów }\end{array}$ \\
\hline Przekonania & $\begin{array}{l}\text { - niemerytoryczne wzory postaw } \\
\text { - negatywne postrzeganie aktorów sceny } \\
\text { politycznej } \\
\text { - krytyczna percepcja wpływu na zmiany } \\
\text { systemowe }\end{array}$ & $\begin{array}{l}\text { - liczne kontrowersje wokół obsady ważnych } \\
\text { stanowisk publicznych } \\
\text { - niski prestiż polityków } \\
\text { - krytyczne oceny instytucji publicznych } \\
\text { - postrzeganie szans sukcesu życiowego }\end{array}$ \\
\hline Zachowania & $\begin{array}{l}\text { - konfrontacyjny styl sprawowania władzy } \\
\text { i prowadzenia polityki } \\
\text { - grupy wpływu narzucające partykularne } \\
\text { interesy } \\
\text { - znacząca korupcja polityczna i administracyjna } \\
\text { - wyobcowanie „klasy politycznej” }\end{array}$ & $\begin{array}{l}\text { - nadmierne upartyjnienie dyskursu publicznego } \\
\text { i decyzji politycznych } \\
\text { - strategie klientelistyczne, syndykalistyczne, } \\
\text { korporatywistyczne, nepotyzm, kolesiostwo } \\
\text { - częstotliwość oskarżeń związanych } \\
\text { z nadużywaniem władzy } \\
\text { - wysoka absencja wyborcza }\end{array}$ \\
\hline
\end{tabular}

Źródło: opracowanie własne.

\section{Inne przesłanki słabości merytokratyzmu w Polsce}

Proces wprowadzania zasad merytokratyzmu do polityki państwa ma długą historię. Jest wynikiem przede wszystkim wzrostu znaczenia mieszczaństwa i klas

wyborców. Inicjatywy z różnych krajów świata, red. A. Ellis, M. Gratschew, Instytut Spraw Publicznych, Warszawa 2009, s. 166-199.

68 W literaturze spotyka się również pogląd, że wysokie uczestnictwo wyborcze może mieć destrukcyjny wpływ na demokrację, jak w Niemczech i Austrii w latach 30. XX w. Nagły wzrost frekwencji wyborczej wzmacnia czasem głosujących z poglądami autorytarnymi, preferujących silnych przywódców. Duży poziom partycypacji wyborczej jest korzystny wtedy, gdy ma charakter stopniowy i jest przygotowany m.in. poprzez wyższy poziom edukacji. S.M. Lipset, Homo politicus, WN PWN, Warszawa 1995, s. 232-234. 
średnich. To one były najsilniej zainteresowane tymi zasadami. W państwach zachodnich przełamywały średniowieczne, tradycyjne reguły ładu społecznego opartego na dziedziczeniu godności, feudalnych zależnościach i zobowiązaniach. Zmieniały także mentalność i osłabiały obowiązywanie praw zrodzonych z dominującej roli wielkiej własności ziemskiej ${ }^{69}$.

W państwach zachodnich rozwój reguł merytokratycznych był silnie sprzężony $z$ rozwojem i rosnącą legitymizacją przemian rynkowych i demokratycznych. Proces ten stał się ważnym aspektem modernizacji napędzanej przez powstanie kapitalizmu i rewolucję przemysłową, które generowały wzrost znaczenia statusu zdobytego, a nie przypisanego, indywidualizm oraz świecki charakter społeczeństwa ${ }^{70}$. Społeczeństwo polskie było i jest w tym zakresie odmienne od wysoko rozwiniętych państw kapitalistycznych. Wskaźnikiem tej odmienności jest niższy poziom rozwoju gospodarczego i kształt struktury społeczno-zawodowej wyróżniającej się stosunkowo wysokim odsetkiem właścicieli gospodarstw i robotników rolnych (12 proc.) oraz robotników wykwalifikowanych i niewykwalifikowanych (łącznie 39 proc.). Równocześnie występuje relatywnie niewielki udział wyższych kadr kierowniczych i specjalistów - 7,6 proc., czyli warstw społecznych, które w państwach zachodnich wraz z częścią przedsiębiorców (w Polsce stanowiących 5,1 proc.) tworzą rdzeń klas średnich, uznawanych za największych orędowników orientacji merytokratycznej ${ }^{71}$.

W Polsce płytki charakter społecznego zaplecza tej orientacji oddają również dane dotyczące poziomu wykształcenia. Wykształcenie wyższe ma 16 proc. Polaków, jedna trzecia - wykształcenie średnie wraz z policealnym, a reszta - zasadnicze zawodowe i poniżej (12 proc. posiada wykształcenie podstawowe i niepełne podstawowe). Trzeba też uwzględnić przestrzenną koncentrację wykształcenia w miastach, zwłaszcza dużych. Na wsi wyższe wykształcenie ma 9,9 proc., a zasadnicze zawodowe i poniżej - 53 proc. dorosłych mieszkańców ${ }^{72}$. Nawet jeśli uwzględnimy „rewolucję edukacyjną", która zachodzi w młodym pokoleniu, to przytoczone dane obrazują liczebne, społeczne i przestrzenne ograniczenia potencjalnego zaplecza merytokratyzmu. Wyjaśniają też one częściowo strukturalne przesłanki słabości recepcji jego założeń w praktyce życia społecznego.

W efekcie na obecnym etapie rozwoju społeczeństwa polskiego i jego kultury politycznej znacząca część polityków trafnie rozpoznaje nastroje społeczne jako

${ }^{69}$ M. Bloch, Społeczeństwo feudalne, PIW, Warszawa 2002.

${ }_{70}$ R. Inglehart, P. Norris, Wzbierajaca fala. Równouprawnienie płci a zmiana kulturowa na świecie, PIW, Warszawa 2009, s. 26.

${ }^{71}$ H. Domański, Formowanie sie „nowych” struktur społecznych, w: W. Adamski, Fenomen „Solidarności" i zmiana ustroju. Polacy 1980-2011, IFiS PAN, Warszawa 2014, s. 361-378.

72 Rocznik Demograficzny 2014, GUS, Warszawa, s. 171. 
niewymuszające kierowania się standardami merytokratycznymi w sferze publicznej. Konkretyzację takiego podejścia stanowią hasła i postawy populistyczne oraz antyestablishmentowe, zakorzenione $\mathrm{w}$ tradycji pomijania instytucji w działaniach politycznych, dezawuujące wartości wyznawane przez elity w celu marginalizacji roli demokratycznych norm i procedur, którym przeciwstawia się charyzmatycznych przywódców ${ }^{73}$. W takich warunkach ważnym systemowo zagadnieniem jest stosunek rządów do profesjonalizacji zarządzania i odpolitycznienia administracji publicznej, doboru kandydatów do rad nadzorczych spółek z udziałem skarbu państwa, a także regulacji dotyczących służby cywilnej, w tym wymogów kompetencyjnych stawianych kandydatom na kierownicze stanowiska ${ }^{74}$.

Analizy porównawcze prowadzą do wniosku, że wysoce profesjonalny państwowy aparat biurokratyczny - np. w Niemczech czy we Francji - pełni funkcje stabilizujące porządek demokratyczny. Polska, jak wiele innych krajów trzeciej fali demokratyzacji charakteryzowanej niegdyś przez Huntingtona, nie dysponuje takim aparatem. Wraz ze słabo rozwiniętymi mechanizmami państwa opiekuńczego i partiami tworzonymi wokół charyzmatycznych przywódców taka sytuacja oznacza prawdopodobieństwo większego zagrożenia dla demokracji niż w państwach zachodnich ${ }^{75}$.

$* * *$

We współczesnych społeczeństwach jednym z ważnych źródeł prawomocności władzy są postulaty merytokracji, definiowanej dwojako w kategoriach rosnącej korelacji wykształcenia z wynagrodzeniem bądź też rządów warstwy „najlepiej przygotowanych" profesjonalistów.

W Polsce po 1989 r. oczekiwano, że liberalne reformy ustrojowe uruchomią procesy modernizacji i zmian strukturalnych, które wraz z regułami rynku i ekspansją klas średnich relatywnie szybko wprowadzą standardy merytokratyczne w społeczeństwie. Proces ten został wzmocniony także przez działalność inwestorów zagranicznych i akcesję z UE.

Jednak w organach władzy i administracji państwowej występuje wiele czynników, które wyraźnie osłabiają działanie zasad merytokracji i są przenoszone również na inne obszary życia społecznego. Niska efektywność tych instytucji (sytuująca Polskę wśród słabo zarządzanych państw w UE) powoduje, że postulaty merytokracji jedynie w niewielkim zakresie stały się zasobem prawomocności władzy. Także

${ }^{73}$ Demokracja w obliczu populizmu, red. J. Szacki, Oficyna Naukowa, Warszawa 2007.

${ }^{74}$ K. Burnetko, op.cit.; M. Kwiatkowski, Nieprzejrzystośćc.., op.cit.; A. Zybała, Potencjał strategiczny państwa - warunkiem jego bezpieczeństwa. Diagnoza sytuacji, kierunki na przyszłość, w: Współczesne zagrożenia a polityka publiczna, Akademia im. J. Długosza, Częstochowa 2015.

${ }^{75}$ H. Kitschelt, Gra w trzy karty, „Polityka”, 21-27 września 2016. 
rozpatrywanie rządzących w kategoriach warstwy „najlepiej przygotowanych” nie znajduje uznania w świadomości społecznej i opiniach ekspertów, co potwierdzają badania nad prestiżem i społeczną oceną instytucji publicznych, jak krajowe i międzynarodowe badania ich działania i efektywności.

W Polsce (jak w innych krajach pokomunistycznych), taka sytuacja w znacznej mierze zakorzeniona jest w dziedzictwie instytucjonalnym, wzorcach kulturowych i strategiach działań głównych społecznych podmiotów zmian, znacząco odbiegających od współczesnych standardów merytokracji alokacyjnej lub dystrybucyjnej. Wskaźnikowym przejawem ich występowania są m.in. dyskusje wokół zakresu i form zawłaszczania państwa, kapitalizmu sektora publicznego bądź instytucjonalizacji nieodpowiedzialności. Wskazują one na podporządkowanie zasady merytokratyzmu preferencjom politycznym, interesom grupowym i jednostkowym korzyściom, które w skali społecznej prowadzą do znacznego marnotrawstwa kapitału ludzkiego i podważania wiarygodności instytucji państwa.

Wśród wybranych czynników redukujących zakres merytokratyzmu w instytucjach ustrojowych w wymiarze reguł szczególne znaczenie mają: zawłaszczanie państwa przez partie polityczne, wadliwe mechanizmy selekcji rządzących, przestarzały model administracji publicznej, niska jakość regulacji, słabość rządów prawa i ułomne procedury reprezentacji politycznej. W aspekcie przekonań - rozpowszechnienie niemerytorycznych wzorów postaw w sferze publicznej, negatywne postrzeganie podmiotów polityki i krytyczna percepcja wpływu instytucji ustrojowych na zmiany systemowe, które dystansują Polaków wobec pozytywnego myślenia o roli państwa w ogólności. W wymiarze zachowań analogiczną funkcję pełnią: konfrontacyjny styl sprawowania władzy, efektywność grup wpływu narzucających partykularne interesy, znacząca korupcja polityczna i administracyjna, a także wyobcowanie „klasy politycznej" zniechęcające obywateli do partycypacji politycznej.

Powyższe czynniki zdają się dobrze wpisywać w tezę A. Rycharda, że rok 2015 oznacza w Polsce więcej niż typową zmianę władzy w demokratycznych warunkach. Doszło do niej bowiem m.in. w wyniku wyczerpania się normatywnej podstawy legitymizacyjnej („obietnicy transformacyjnej”) skutecznie działającej w poprzednich latach, opartej na takich wartościach, jak rynek, demokracja lub członkostwo w UE. W takiej perspektywie „być może zmiana roku 2015 symbolizuje głębsze procesy, narastające już wcześniej”76.

${ }^{76}$ A. Rychard, Czy nowy kryzys legitymizacji i stary deficyt zaufania? Wstępne refleksje i empiryczne ilustracje, w: Polska-Europa. Wyniki Europejskiego Sondażu Społecznego 2002-2015, red. P.B. Sztabiński, IFiS PAN, Warszawa 2016, s. 11. 
Są przesłanki, by uznać, że jednym $\mathrm{z}$ takich procesów jest zakwestionowanie idei merytokratycznych przez elity władzy zmieniające się w kolejnych cyklach wyborczych. Ich deprecjacja została dodatkowo wzmocniona przez zmiany strukturalne powodujące malejącą opłacalność wyższego wykształcenia części młodego pokolenia i ograniczenia systemu rekrutacji, których przejawem są prekaryjne formy zatrudnienia. Proces ten wzmocnił także przekonanie o wyczerpaniu dotychczasowej strategii rozwoju gospodarczego kraju podważonej przez globalny kryzys w 2008 r. i jego następstwa nie tylko w Polsce, lecz również w wielu innych państwach.

W takich okolicznościach nowa „obietnica transformacyjna” PiS, adresowana do niższych warstw społecznych i części młodego pokolenia rozczarowanego brakiem perspektyw, traktuje merytokratyzm jako przeszkodę w wymianie elit, legitymizującą beneficjentów liberalno-lewicowej transformacji ustrojowej (partie opozycyjne, korporacje prawnicze, firmy z udziałem inwestorów zagranicznych itd.). Nowy rząd w sferze diagnostycznej dostrzega znaczenie jakości funkcjonowania instytucji publicznych, sprawnej administracji i wzmacniania strategicznego zarządzania procesami rozwojowymi.

Deklaruje wprowadzenie nowego modelu rozwoju gospodarczego i społecznego, określa cele i oczekiwane rezultaty oraz główne obszary koncentracji działań. Jednak w sferze programowej (zob. Strategia na rzecz Odpowiedzialnego Rozwoju, SOR), a tym bardziej w zakresie działań praktycznych, m.in. zmian w służbie cywilnej, mediach publicznych, spółkach skarbu państwa i innych instytucjach podległych rządowi, trudno wskazać przejawy pozytywnego podejścia do idei merytokratycznych. W tym zakresie dokonuje się systemowy regres motywowany „rewolucyjną” koncepcją wymiany elit.

W efekcie rozbudowana część diagnostyczna SOR, zapowiadająca „nowy model rozwoju" jako zasadniczy dokument uzasadniający rosnącą centralizację i koncentrację władzy mającej realizować rozmaite „projekty strategiczne”, „flagowe” oraz „kluczowe”, jest rozbieżna z praktyką polityczną, a nawet zmniejsza szanse jej realizacji.

Takie podejście do merytokratyzmu paradoksalnie powiela w zwiększonej skali krytykowane przez liderów PiS wzorce III RP. Nadaje też ich koncepcjom charakter arbitralny, woluntarystyczny, co w powiązaniu z preferencjami ideologicznymi umniejszającymi rolę profesjonalizmu rodzi skłonność do chaosu normatywnego i regulacyjnego, a także zjawisk korupcyjnych. Niezależnie od intencji bez zmiany tego podejścia trudno oczekiwać podniesienia jakości kadr administracyjnych, formułowania i efektywnego wdrażania polityki czy poprawy poziomu usług publicznych. Czas pokaże, czy strategia legitymizacyjna oparta na krytyce merytokratyzmu okaże się skuteczna, jak długo będzie kontynuowana lub też, czy zostanie zmodyfikowana. 


\section{Bibliografia}

Aktywizowanie wyborców. Inicjatywy z różnych krajów świata, red. A. Ellis, M. Gratschew i in., Instytut Spraw Publicznych, Warszawa 2009.

Alvesson M., Biling Y.D., Kobiety i zarzadzanie: cztery perspektywy teoretyczne, w: Aktorzy życia publicznego, red. R. Siemieńska, Wydawnictwo Naukowe Scholar, Warszawa 2003.

Anticorruption in Transition. Contribution to the Policy Debate, The World Bank, Washington, D.C. 2000.

Badora B., Derczyński W., Falkowska M., Nierówności społeczne, w: Polska Europa Świat. Opinia publiczna w okresie integracji, red. K. Zagórski, M. Strzeszewski, Warszawa 2005.

Baranowska K., Wyborcy potrzebuja czasu, Wywiad z Mirosława Grabowska, „Rzeczpospolita”, 27 października 2009.

Bartkowski J., Politycy jako administratorzy. Elita rządowa jako grupa zarzadzająca, w: Elity rzadowe III RP 1997-2004, red. J. Raciborski, Wydawnictwo Trio, Warszawa 2006.

Beck U., Społeczeństwo ryzyka, Wydawnictwo Naukowe Scholar, Warszawa 2002.

Beetham D., Legitymizacja władzy, w: Władza i społeczeństwo, red. J. Szczupaczyński, Wydawnictwo Naukowe Scholar, Warszawa 1995.

Bloch M., Społeczeństwo feudalne, PIW, Warszawa 2002.

Borzel T.A., Nowe metody zarzadzania a rozszerzenie Unii Europejskiej - paradoks podwójnej słabości, w: materiały konferencji Nowe metody zarzadzania a efektywność administracji publicznej. Rola wyższej kadry zarządzającej, Warszawa 2008.

Bourdieu P., O telewizji. Panowanie dziennikarstwa, Wydawnictwo Naukowe PWN, Warszawa 2009.

Bourdieu P., Passeron J.C., Reprodukcja, Wydawnictwo Naukowe PWN, Warszawa 1990.

Burnetko K., O demokracji w administracji publicznej, w: Demokracja w Polsce 2007-2009, red. L. Kolarska-Bobińska, J. Kucharczyk, Instytut Spraw Publicznych, Warszawa 2009.

Cieślak-Wróblewska A., Połowiczne czystki resortowe, „Rzeczpospolita”, 4 maja 2016.

Cybulska A., Strzeszewski M., Demokracja w działaniu, w: Polska Europa Świat. Opinia publiczna w okresie integracji, red. K. Zagórski, M. Strzeszewski, Wydawnictwo Naukowe Scholar, Warszawa 2005.

Cześnik M., Partycypacja wyborcza Polaków, Instytut Spraw Politycznych, Warszawa 2008.

Cześnik M., Uczestnictwo wyborcze, stosunek do demokracji, legitymizacja władzy. Przypadek Polski, w: Populizm a demokracja, red. R. Markowski, ISP PAN Warszawa 2004.

Demokracja w obliczu populizmu, red. J. Szacki, Oficyna Naukowa, Warszawa 2007.

Doing Business 2010, The World Bank, 2009, http://www.doingbusiness.org/documents/DoingBusiness2007_FullReport.pdf

Domański H., Merytokratyczna dystrybucja i zmiany mobilności: Polska i kraje Europy Środkowo-Wschodniej, w: Do i od socjalizmu, red. A. Siciński, Wydawnictwo IFiS PAN, Warszawa 1998.

Domański H., Prestiż, Fundacja na Rzecz Nauki Polskiej, Wrocław 1999. 
Domański H., Struktura społeczna, Wydawnictwo Naukowe Scholar, Warszawa 2004.

Domański H., Pokropek A., Żółtak T., Stratyfikacja społeczna a zachowania polityczne. Kraje europejskie w latach 2002-2012, IFiS PAN, Warszawa 2015.

Dudek A., Pierwsze lata III Rzeczypospolitej 1981-2001, Arcana, Kraków 2004.

Ellias N., Mozart, Wydawnictwo W.A.B., Warszawa 2006.

Fuszara M., Kobiety, mężczyźni i parytety, Instytut Spraw Publicznych, Warszawa 2009.

Gadowska K., Przemoc w przestrzeni sieci klientelistycznych i kolesiowskich, w: Szara strefa przemocy - szara strefa transformacji? Przestrzenie przymusu, red. R. Sojak, UMK, Toruń 2007.

Gadowska K., Zjawisko klientelizmu polityczno-ekonomicznego. Systemowa analiza powiązań sieciowych na przykładzie przekształceń sektora górniczego w Polsce, Wydawnictwo Uniwersytetu Jagiellońskiego, Kraków 2002.

Gilejko L., Towalski R., Sektor publiczny - dylematy struktury i nowe konflikty, „Obywatel” 2009, nr 2(46).

Gilman N., Mandarins of the Future. Modernization Theory in Cold War America, The Johns Hopkins University Press, Baltimore - London 2007.

Gliński P., Kongres Kultury - stanowisko PTS II, w: „Biuletyn Informacyjny Polskiego Towarzystwa Socjologicznego", Zarząd Główny PTS, Warszawa 2009.

Godzic W., Polskie media a demokracja, w: Demokracja w Polsce. 2007-2009, red. L. Kolarska-Bobińska, J. Kucharczyk, Instytut Spraw Publicznych, Warszawa 2009.

Goetz K., Zubek R., Stanowienie prawa w Polsce. Reguly legislacyjne a jakość ustawodawstwa, Sprawne Państwo Program Ernst \& Young, Warszawa 2005.

Grabowska A., Reforma dialogu społecznego w Polsce. Od zawieszenia do nowej formuly trójstronnej debaty, Fundacja im. Friedricha Eberta, Warszawa 2016.

Grabowska M., Podział postkomunistyczny. Społeczne podstawy polityki w Polsce po 1989 roku, Wydawnictwo Naukowe Scholar, Warszawa 2004.

Greenspan A., Moja ideologia jest błędna. Fragmenty przesłuchania A. Greenspana przez Komitet Nadzoru Bankowego Izby Reprezentantów USA, „Krytyka Polityczna” 2009, t. 8.

Growing Unequal? Income Distribution and Poverty in OECD Countries, OECD, Paris 2008.

Grzymała-Busse A., Rebuilding Leviathan. Party Competition and State Exploitation in Post-Communist Democracies, Cambridge University Press, Cambridge 2007.

Grzymała-Busse A., Redeeming the Communist Past. The Regeneration of Communist Parties in East Central Europe, Cambridge University Press, Cambridge 2002.

Habermas J., Legitimation Crisis, Beacon, Boston 1973.

Hausner J., Marody M., Trzy Polski: potencjał i bariery integracji z Unia Europejska, Fundacja im. Friedricha Eberta, Warszawa 1999.

Heywood A., Politologia, Wydawnictwo Naukowe PWN, Warszawa 2006.

Heywood P., Meyer-Sahling J.-H., Występowanie stref korupcji w zarządzaniu polska administracja rządowa, Sprawne Państwo Program Ernst \& Young, Warszawa 2008. 
Higley J., Pakulski J., Elite Theory and Research in Postcommunist Societies, w: The Second Generation of Democratic Elites in Central and Eastern Europe, red. J. Frentzel-Zagórska, J. Wasilewski, ISP PAN, Warsaw 2000.

Indeks Społeczeństwa Obywatelskiego w Polsce, Stowarzyszenie Klon/Jawor, Warszawa 2006.

Inglehart R., Norris P., Wzbierająca fala. Równouprawnienie płci a zmiana kulturowa na świecie, PIW, Warszawa 2003.

Jakość rzadzenia: Polska bliżej Unii Europejskiej?, red. J. Hausner, M. Marody, Akademia Ekonomiczna - Fundacja im. Friedricha Eberta, Kraków 2000.

Jałowiecki B., Łukowski W., Gettoizacja polskiej przestrzeni miejskiej, Scholar - Szkoła Wyższa Psychologii Społecznej, Warszawa 2007.

Janecki S., Analfabeci polityki, „Wprost”, 21 czerwca 2009.

Jarosz M., Władza. Przywileje. Korupcja, Wydawnictwo Naukowe PWN - ISP PAN, Warszawa 2004.

Jasiecki K., Elita biznesu w Polsce, IFiS PAN, Warszawa 2002.

Jasiecki K., Konsens i konflikt w pogladach elity politycznej, w: Polityka i Sejm: formowanie sie elity politycznej, red. W. Wesołowski, B. Post, Wydawnictwo Sejmowe, Warszawa 1998.

Jasiecki K., Kapitalizm po polsku. Między modernizacją a peryferiami Unii Europejskiej, Wydawnictwo IFiS PAN, Warszawa 2013.

Jasiecki K., Molęda-Zdziech M., Kurczewska U., Lobbing, Oficyna Ekonomiczna, Kraków 2006.

Jasiewicz K., Polska u progu Unii Europejskiej: referendum akcesyjne a deficyt demokratyczny, w: Populizm a demokracja, red. R. Markowski, Wydawnictwo ISP PAN, Warszawa 2004.

Jasińska-Kania A., Orientacje aksjologiczne Polaków na tle europejskim, w: Oswajanie wielkiej zmiany, red. I. Krzemiński, J. Raciborski, Wydawnictwo Instytut Socjologii UW, Warszawa 2007.

Judt T., Postwar. A History of Europe Since 1945, Penguin Group, New York 2005.

Kamiński A., Korupcja jako symptom instytucjonalnej niewydolności państwa i zagrożenie dla rozwoju polityczno-gospodarczego Polski, w: Dobro wspólne, władza, korupcja, red. E. Popławska, Instytut Spraw Publicznych, Warszawa 1997.

Kamiński A., Polityczne uwarunkowania sprawności administracji publicznej: przypadek pokomunistycznej Polski, w: materiały konferencji $W$ drodze do demokratycznego państwa prawa. Polska 1989-2009, Rzecznik Praw Obywatelskich, Warszawa 2009.

Kamiński A., Kurczewska J., Institutional Transformations in Poland: The Rise of Nomadic Political Elites, w: The Transformation of Europe, red. M. Alestalo, E. Allard, W. Wesołowski, Wydawnictwo IFiS PAN, Warszawa 1994.

Karklins R., Wszystkiemu winien system. Korupcja w krajach postkomunistycznych, Wydawnictwo Sic!, Warszawa 2009.

Kauffman D., Krasy A., Mastruzzi M., Governance Matters VIII: Governance Indicators for 1996-2008, World Bank Policy Research, 2009, www.govindicators.org

Konarzewski K., Reforma oświaty. Podstawa programowa i warunki kształcenia, Instytut Spraw Publicznych, Warszawa 2004. 
Kotowska I.E., Matysiak A., Rynek pracy, w: Statystyka społeczna, red. T. Panek, PWE, Warszawa 2007.

Kozak M.W., Wykluczenie - rozwój - przestrzeń, w: Wykluczeni. Wymiar społeczny, materialny i etniczny, red. M. Jarosz, Wydawnictwo ISP PAN, Warszawa 2008.

Kwiatkowski M., Dlaczego obawiamy się merytokracji kadrowej? Spojrzenie socjologa, „Przegląd Służby Cywilnej”, Departament Służby Cywilnej Kancelarii Prezesa Rady Ministrów, październik 2014.

Kwiatkowski M., Nieprzejrzystość. Bariery merytokracji kadrowej w sektorze publicznym, Oficyna Wydawnicza Uniwersytetu Zielonogórskiego, Zielona Góra 2011.

Lasch Ch., Bunt elit, Wydawnictwo Platan, Kraków 1997.

Lipset S.M., Homo politicus, Wydawnictwo Naukowe PWN, Warszawa 1995.

Mandes S., Doświadczenie urzędników administracji publicznej we współpracy z partnerami zachodnimi, w: Kulturowe aspekty transformacji ekonomicznej, red. J. Kochanowicz, S. Mandes, M. Marody, Instytut Spraw Publicznych, Warszawa 2007.

Markowski R., System wyborczy - system partyjny - jakość demokracji. O jednomandatowych okregach wyborczych, Instytut Spraw Publicznych, Warszawa 2010.

Marshall G., Swift A., Meritocratic Equality of Opportunity: Economic Efficiency, Social Justice, or Both?, "Policy Studies" 1997, No. 18.

Morawski W., Zmiana instytucjonalna, Wydawnictwo Naukowe PWN, Warszawa 1998.

Murawska B., Segregacja na progu szkoły podstawowej, Instytut Spraw Politycznych, Warszawa 2004.

Peters G.B., Administracja publiczna w systemie politycznym, Wydawnictwo Naukowe Scholar, Warszawa 1999.

Poczatki parlamentarnej elity, red. J. Wasilewski, W. Wesołowski, Wydawnictwo IFiS PAN, Warszawa 1992.

Polska 2030. Wyzwania rozwojowe, red. M. Boni, Zespół Doradców Strategicznych Prezesa Rady Ministrów, Warszawa 2009.

Polska $w$ dialogu. Tradycja, zmiany, porównanie perspektywy, red. A. Zybała, CPS „Dialog”, Warszawa 2016.

Pratkanis A., Aronson E., Wiek propagandy. Używanie i nadużywanie perswazji na co dzień, Wydawnictwo Naukowe PWN, Warszawa 2004.

Przejrzystość procesu stanowienia prawa, red. G. Kopińska i in., Fundacja im. Stefana Batorego, Warszawa 2008.

Putnam R., Demokracja w działaniu, Znak, Kraków 1995.

Raport o kapitale intelektualnym Polski, Zespół Doradców Prezesa Rady Ministrów, Kancelaria Prezesa Rady Ministrów, Warszawa 2008.

Roguska B., Opinia publiczna o demokracji, Demokracja w Polsce 2005-2007, red. L. Kolarska-Bobińska, J. Kucharczyk, J. Zbieranek, Instytut Spraw Publicznych, Warszawa 2007.

Ruszkowski P.R., Dysfunkcjonalne grupy interesów a system społeczny, w: Szara strefa przemocy - szara strefa transformacji? Przestrzenie przymusu, red. R. Sojak, Uniwersytet Mikołaja Kopernika, Toruń 2007. 
Rychard A., Czy nowy kryzys legitymizacji i stary deficyt zaufania? Wstęne refleksje i empiryczne ilustracje, w: Polska-Europa. Wyniki Europejskiego Sondażu Społecznego 2002-2015, red. P.B. Sztabiński, IFiS PAN, Warszawa 2016.

Ryszka F., Państwo stanu wyjątkowego, Ossolineum, Warszawa-Wrocław 1985.

Satori G., Homo videns. Telewizja i postmyślenie, Wydawnictwa Uniwersytetu Warszawskiego, Warszawa 2007.

Schenk D., Hans Frank, Wydawnictwo Znak, Kraków 2009.

Słomczyński K.M., „Merytokratyzm” a efektywność alokacyjna i dystrybucyjna w Polsce w latach 1965-1995, w: Do i od socjalizmu, red. A. Siciński, Wydawnictwo IFiS PAN, Warszawa 1998.

Słomczyński K.M., Janicka K., Pęknięta struktura społeczeństwa polskiego, w: Polska. Ale jaka?, red. M. Jarosz, Instytut Nauk Politycznych PAN, Warszawa 2005.

Słownik politologii, red. B. Walicka, Wydawnictwo Naukowe PWN, Warszawa 2008.

Słownik socjologii i nauk społecznych, red. G. Marshall, Wydawnictwo Naukowe PWN, Warszawa 2005.

Staniszkis J., Postkomunizm, Wydawnictwo słowo/obraz/terytoria, Gdańsk 2001.

Staniszkis J., Władza globalizacji, Wydawnictwo Naukowe Scholar, Warszawa 2003.

Stark D., Bruszt L., Postsocialist Pathways. Transforming Politics and Property in East Central Europe, Cambridge University Press, Cambridge 1998.

Stark D., Recombinant Property in East European Capitalism, "American Journal of Sociology" 1996, No. 101.

Stiglitz J., Globalizacja, Wydawnictwo Naukowe PWN, Warszawa 2004.

Szacki J., Liberalizm po komunizmie, Fundacja im. Stefana Batorego, Warszawa-Kraków 1995.

Tarkowski J., Socjologia świata polityki, t. 1, Wydawnictwo ISP PAN, Warszawa 1994.

The East Asian Miracle, The World Bank, Oxford University Press, Oxford 1993.

Thurow L.C., Powiększanie bogactwa. Nowe reguly gry w gospodarce opartej na wiedzy, Wydawnictwo Helion, Warszawa 2006.

Uczestnictwo w wyborach i kampaniach wyborczych po 1989 roku, red. J. Fras, UW, Wrocław 2009.

Walecki M., Zbieranek J., Finansowanie polityki, w: Demokracja w Polsce 2005-2007, red. L. Kolarska-Bobińska, J. Kucharczyk, J. Zbieranek, Instytut Spraw Publicznych, Warszawa 2007.

Wallerstein I., Koniec świata jaki znamy, Wydawnictwo Naukowe Scholar, Warszawa 2004.

Wallerstein I., The Decline of American Power, The New Press, New York 2003.

Wasilewski J., Wnuk-Lipiński E., Polska: kręta droga od elity komunistycznej do postsolidarnościowej, w: Elity w Polsce, Rosji i na Węrzech, red. I. Szelenyi, D. Treiman, E. Wnuk-Lipiński, Wydawnictwo ISP PAN, Warszawa 1995.

Weber M., Gospodarka i społeczeństwo, Wydawnictwo Naukowe PWN, Warszawa 2002.

Wedel J.R., Collision and Collusion. The Strange Case of Western Aid to Eastern Europe, Palgrave, New York 2001. 
Wedel J.R., Klany, kliki i zawłaszczone państwo. O przedefiniowaniu „przejścia” w Europie Środkowo-Wschodniej i dawnych republikach Zwiazku Radzieckiego, w: Szara strefa przemocy - szara strefa transformacji? Przestrzenie przymusu, red. R. Sojak, Uniwersytet Mikołaja Kopernika, Toruń 2007.

Wenzel M., Strzeszewski M., Polacy wobec demokracji, w: Polska Europa Świat. Opinia publiczna w okresie integracji, red. K. Zagórski, M. Strzeszewski, Wydawnictwo Naukowe Scholar, Warszawa 2005.

Wesołowski W., Merytokracja, w: Encyklopedia socjologii, t. 2, Oficyna Naukowa, Warszawa 1999.

White S., Równość, Wydawnictwo Sic!, Warszawa 2008.

Young M., The Rise of the Meritocracy 1870-2033, Thames and Hudson, London 1958.

Zakaria F., The Future of Freedom, W.W. Norton \& Company, New York-London 2004.

Zbieranek J., Finansowanie partii politycznych $w$ Polsce - czy i jakie zmiany?, Fundacja im. S. Batorego, 2015, http://www.batory.org.pl/upload/files/Programy\%20operacyjne/PolicyPaper_Finansowanie\%20partii.pdf

Zbieranek J., Zmiany w systemie prawa wyborczego i finansowanie partii politycznych, w: Demokracja w Polsce 2007-2009, red. L. Kolarska-Bobińska, J. Kucharczyk, Instytut Spraw Publicznych, Warszawa 2009.

Zielonka J., Europe as Empire. The Nature of the Enlarged European Union, Oxford University Press, Oxford 2006.

Zubek R., Matczak M., Cieleń A., Zalasiński T., Barometr Legislacyjny. Analiza wykonania programu prac legislacyjnych Rady Ministrów na I pótrocze 2009 r., Sprawne Państwo Program Ernst \& Young, Warszawa 2010.

Zybertowicz A., Przemoc „układu”. O peerelowskich korzeniach sieci biznesowej Zygmunta Solorza, w: Transformacja podszyta przemoca. O nieformalnych mechanizmach przemian instytucjonalnych, red. R. Sojak, A. Zybertowicz, Uniwersytet Mikołaja Kopernika, Torun 2008.

Zybertowicz A., Demokracja jako fasada: przypadek III RP, w: Utracona dynamika? O niedojrzałości polskiej demokracji, red. E. Mokrzycki, A. Rychard, A. Zybertowicz, Wydawnictwo IFiS PAN, Warszawa 2002. 